\title{
POR UMA TEORIA ESPACIAL DO PARENTESCO
}

Klaus Hamberger

\section{Introdução}

Desde os trabalhos de Courrège (1965), Lorrain (1975) e Tjon Sie Fat (1990), sabe-se que as estruturas de parentesco ditas "elementares" (aquelas que permitem exprimir a aliança matrimonial em termos inteiramente genealógicos) constituem "espaços" no sentido algébrico do termo (isto é, conjuntos sobre os quais age um grupo regular de permutações). Concebido como uma simples reformulação matemática da teoria lévistraussiana da troca matrimonial, esse resultado não foi, entretanto, visto como dotado de um valor heurístico independente. Em particular, não se o empregou para uma melhor compreensão das estruturas de parentesco que, sem serem "elementares" e/ou sem se mostrarem interpretáveis como estruturas de troca, exibem, não obstante, as propriedades formais dos "espaços": a saber, de estruturas que, sem permitir uma definição da aliança matrimonial em termos puramente genealógicos, admitem uma tal definição em combinação com outras relações (sobretudo aquelas que remetem ao espaço físico). O fato empírico de que diversas estruturas de parentesco se inscrevem efetivamente no espaço físico, e se fazem legíveis na morfologia dos hábitats, deveria ter fortalecido consideravelmente uma tal concepção "espacial" do parentesco, concepção que, no limite, conduziria à fusão da antropologia do espaço e da antropologia do parentesco em uma teoria unitária do espaço social. Tal potencial, todavia, não foi explorado. De onde advém essa esterilidade teórica de um modelo matemático que, malgrado a riqueza dos dados empíricos que se prestariam à sua aplicação, limita-se a reconstatar teorias preexistentes?

A principal razão parece estar no fato de que a noção de espaço — diferentemente da noção de troca - não se apresenta como uma noção propriamente sociológica. Além disso, a noção de troca designa uma estrutura 
de comunicação recíproca, o que faz dela uma noção evidentemente incomensurável com uma noção de espaço concebido (na tradição pós-kantiana) como forma do conhecimento sensível do sujeito individual. Mas esta última concepção não é a única possível. Ela foi seriamente posta em questão no início do século XX em prol de uma interpretação alternativa do espaço como uma estrutura da percepção cuja construção envolve a indispensável interação de vários sujeitos: assim, Reichenbach apresentava, em 1928, um modelo para derivar a métrica espaço-temporal do mundo físico de uma rede de observadores (de dimensão corpuscular) comunicando-se entre si por meio de sinais óticos. Com efeito, esta concepção do espaço como estrutura de comunicação recíproca estava longe de ser revolucionária: como sublinhavam Reichenbach, Carnap e outros filósofos do espaço críticos de Kant, ela não era senão um desenvolvimento moderno do modelo de conhecimento elaborado por Leibniz no princípio do século XVIII. Ora, esse modelo leibniziano tem, para nossos propósitos, um duplo interesse. Em primeiro lugar, ele caracteriza o mundo como um sistema de percepções mútuas cuja propriedade fundamental - a "harmonia" das relações percebidas com as relações entre as percepções - é formalmente equivalente à definição algébrica do espaço acima evocada (definição ainda estrangeira à matemática leibniziana). Em segundo lugar, ele é explicitamente erigido como um modelo geral que compreende o conhecimento simbólico assim como o conhecimento sensível, isto é, a interação dos "espíritos" assim como a interação dos corpos. De fato, era graças a essa estrutura de comunicação recíproca que Leibniz caracterizava a "reunião de todos os espíritos" como uma "sociedade".

Certamente, se o modelo leibniziano do espaço físico recuperou toda sua importância com o abalo do modelo newtoniano-kantiano no início do séc. XX, sua extensão ao mundo social permanecia até agora um resultado de reflexões puramente a priori, sem nenhuma conexão visível com as ciências empíricas. Leibniz bem observara (assim como Lewin e Reichenbach depois dele) que seria perfeitamente possível construir um espaço a partir de relações genealógicas, mas nenhum desses filósofos imaginou considerar estruturas genealógicas empíricas como atualizações de uma tal construção. É apenas com a obra de Lévi-Strauss que essa idéia adquire um sentido concreto. Uma vez suposto que os humanos constroem suas estruturas de parentesco como estruturas simbólicas, torna-se possível perguntar se a propriedade estrutural do espaço não passa realmente de um efeito secundário das estruturas de troca ou se o inverso não seria o verdadeiro, e a aparição de estruturas de troca não constituiria senão o resultado de um método particular de construção de estruturas espaciais. 
Esta é a questão que quero discutir neste artigo, examinando primeiramente a justificativa teórica, depois o poder explicativo de um modelo "espacial" do parentesco, que compreenda o modelo aliancista como um caso particular. Irei assim, em um primeiro momento, abordar a questão de qual seria a função social de uma estrutura espacial. Em um segundo momento, vou comparar diferentes estruturas de parentesco - elementares e outras - tal como se inscrevem empiricamente nos espaços de aldeias e acampamentos, para saber se o modelo proposto dá conta, melhor do que o modelo restrito da troca, de suas variações e de seus traços invariantes.

\section{Idéia central e fundamentos teóricos}

\section{O conceito do espaço como estrutura de percepções}

Começo pela apresentação de um conceito geral de espaço enquanto estrutura de um sistema de permutações mútuas. Grande parte do que se segue é, com efeito, um desenvolvimento de idéias e argumentos leibnizianos - mas não se trata, entenda-se, de oferecer uma interpretação de Leibniz. Pretendo apenas indicar aqui o que devo a esse filósofo.

Imaginemos um universo de indivíduos no qual cada um forma uma certa imagem de si mesmo e de cada um dos outros, o conjunto dessas imagens constituindo a percepção de cada indivíduo. Suponhamos que as percepções de todos os indíviduos são comparáveis entre si - no sentido de que a toda imagem figurando na percepção de um indíviduo corresponda exatamente uma imagem figurando na percepção de qualquer outro e que duas imagens equivalentes a uma terceira são também equivalentes entre si. Podemos então estabelecer uma equivalência entre as imagens correspondentes dizendo que elas representam a mesma posição, e caracterizar a diferença entre duas percepções quaisquer por uma permutação dessas posições.

Em uma tal estrutura, há duas maneiras de caracterizar a relação entre dois indivíduos: seja enquanto sujeitos de percepção, pela permutação que substitui a perspectiva de um pela do outro; seja enquanto objetos de percepção, por todas as permutações que fazem com que, por uma mudança de perspectiva adequada, um apareça na posicão do outro. Ora, o conjunto dessas posições constitui um espaço se a toda relação "objetiva" corresponde exatamente uma permutação "subjetiva"; dito de outro modo, se, para toda posição A, existe exatamente uma mudança de perspectiva que a transforma na posição $B$, e que pode portanto ser caracterizada 
sem ambigüidade seja por essa transformação em si mesma, seja pelas transformações "paralelas" de C em D, E em F etc. Dadas três posições A, B, C, a estrutura espacial permite assim indicar sempre uma posição única D tal que C esteja para D assim como A está para B (cf. Fig. 1a). Em outras palavras, um espaço se caracteriza pela possibilidade de "transportar" a relação entre duas posições A e B a qualquer outra posição C.

Para melhor compreender as implicações dessa correspondência unívoca entre relações "objetivas" (posições relativas) e permutações "subjetivas" (mudanças de perspectiva), consideremos separadamente as duas condições parciais de que ela se compõe.

Primeiramente, é preciso que, para quaisquer duas posições, exista pelo menos uma permutação que transforme uma na outra. Essa condição estará assegurada se existir uma posição que todo indivíduo pode ocupar, de uma perspectiva apropriada - como, por exemplo, a posição que todo indivíduo atribui a si mesmo (uma posição de "ego"). Neste último caso, a adoção da perspectiva de um outro acarretará sempre a transformação de sua posição em posição de ego, e toda transformação "subjetiva" entre as perspectivas de dois sujeitos implicará, portanto, uma transformação "objetiva" entre suas posições. Se, pelo contrário, toda posição fosse reservada exclusivamente a uma certa parte dos indivíduos, essa condição não seria realizada (por exemplo, nenhuma permutação poderia transformar um ego feminino em ego masculino).

Em segundo lugar, é preciso que, para quaisquer duas posições, exista no máximo uma permutação que transforme uma na outra. Isso implica que nenhuma permutação pode mudar a posição de um indivíduo sem com isso mudar igualmente a de todos os outros e, em particular, a posição de "ego": não se pode adotar duas perspectivas diferentes sem mudança no ponto de vista. Para conhecer a posição que A atribui a B, deve ser suficiente conhecer as posições que os dois ocupem na percepção de um sujeito $\mathrm{C}$ qualquer. Por exemplo, o fato de que $\mathrm{A}$ e $\mathrm{B}$ ocupem respectivamente a posição de "pai" e "tio materno" deve ser suficiente para concluir que B é um "cunhado"para A, sem que haja possibilidade de que este último o considere alternativamente como um "irmão".

Satisfeitas essas duas condições, a diferença entre as percepções de dois indivíduos depende unicamente de suas posições percebidas. Conseqüentemente, toda permutação de posições, toda "mudança de perspectiva", pode ser associada de maneira unívoca a uma posição (a saber, àquela que essa permutação transformará em ego): localizar um indivíduo é o mesmo que saber como ele localiza todos os outros - perceber o outro implica, em uma certa medida, perceber também sua percepção do mundo. 
Vejamos agora algumas conseqüências formais dessa correspondência entre posições e permutações. Todo grupo de permutações impõe uma estrutura classificatória ao conjunto sobre o qual age: toda permutação engendra uma partição desse conjunto em classes de equivalência, que reagrupam os elementos tornados mutuamente convertíveis seja por essa permutação ela mesma, seja por seu inverso, seja por uma permutação resultante de sua aplicação repetida (por exemplo, a partição engendrada por uma permutação "pai" classificaria ego com o pai, o avô, o filho etc, ao mesmo tempo em que classificaria o cunhado com o sogro, o sobrinho etc. - ela constituiria portanto um sistema de patrilinhas). O conjunto das partições engendradas por todas as permutações de um grupo constitui então a estrutura classificatória correspondente a este último. Ora, caso se trate de um grupo regular - isto é, se o conjunto assim repartido é um espaço - todas as classes engendradas por uma mesma permutação serão isomorfas (o que implica, em particular, que elas conterão o mesmo número de posições). Neste caso, as classes mais englobantes (quer dizer, aquelas que não estão mais contidas em outras classes) podem ser identificadas a retas, e os subgrupos de permutações que as engendram podem ser considerados como direções. A estrutura classificatória de um espaço repousa portanto sobre uma grade de retas ${ }^{1}$ (ver Fig. 1a).

\section{Figura 1a: Estrutura espacial}

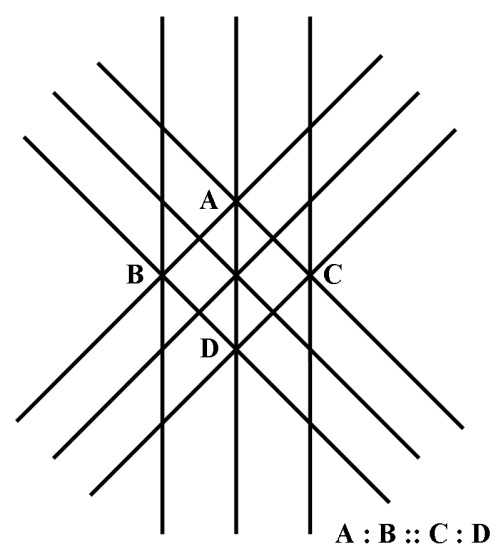

Note-se que essas retas nao sao nem orlentadas - nao podemos distinguir duas percepções segundo representem dois estados "sucessivos" ou "simultâneos" — nem organizadas em qualquer sistema de referência — 
não podemos distinguir duas percepções segundo representem dois estados do "mesmo" sujeito ou de sujeitos "diferentes". Para que tais distinções tornem-se possíveis, é preciso que a estrutura espacial seja especificada por uma estrutura temporal e por uma estrutura de substâncias.

Um espaço adquire uma estrutura temporal pela distinção de certas permutações (consideradas como ações) de maneira que toda combinação de ações é igualmente uma ação. Dir-se-á então que uma ação leva de uma percepção precedente a uma percepção subseqüente, e que a primeira representa a causa da segunda (essa identificação do laço temporal com o laço causal, formulada pela primeira vez nos Initia de Leibniz, constitui o pivô da "teoria causal do tempo" desenvolvida em princípios do séc. XX). Uma tal distinção divide o conjunto das direções em direções espaciais propriamente ditas, de um lado, e direções temporais de outro, conforme as permutações que as engendrem sejam ou não do mesmo tipo que seu inverso: o inverso de uma ação temporal não é jamais uma ação (chamaríamo-lo antes de uma paixão), enquanto toda ação espacial (se há uma) acarreta uma ação recíproca. Da mesma maneira, a distinção entre as ações divide o conjunto das posições em três grandes regiões (o passado, o futuro e a simultaneidade), de modo que o sujeito vai perceber como passadas as posições dos sujeitos que agem sobre ele (quer dizer, daqueles de quem ele recebe sua percepção), como futuras aquelas dos sujeitos sobre quem ele age (quer dizer, aqueles aos quais ele transmite sua percepção), e como simultâneas aquelas dos sujeitos com os quais ele ou interage em ambos os sentidos, ou não interage em absoluto (ver Fig. 1b, onde as três regiões são representadas respectivamente pelas posições A, D e C, a posição de ego sendo B).

\section{Figura 1b: Estrutura temporal}

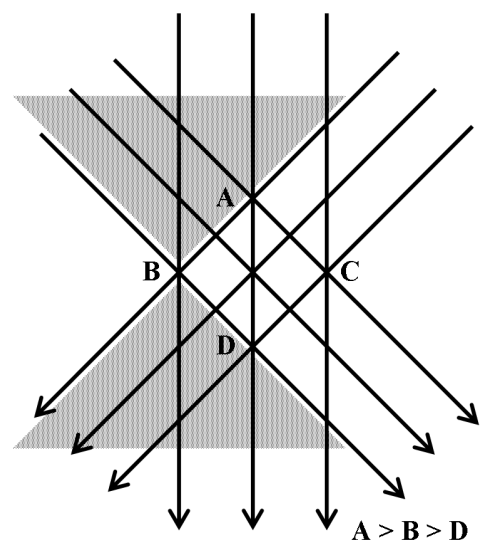


Uma estrutura espaço-temporal implica pois que consideremos o sistema de percepções mútuas como um sistema de interação. Em termos de parentesco, a definição de uma estrutura temporal equivale à distinção das relações de procriação, distinção que acarreta a divisão do espaço do sujeito em um passado que compreende seus ancestrais, um futuro que compreende sua progenitura, e uma simultaneidade que compreende seus colaterais.

Enfim, um espaço com uma estrutura temporal adquire uma estrutura de substâncias se uma direção temporal se distingue de todas as outras enquanto a direção "natural" característica do desenvolvimento sucessivo de um único e mesmo sujeito. Conceber o sujeito percipiente como uma substância é o mesmo pois que caracterizá-lo por toda a série de percepções que resultam uma da outra segundo uma mesma permutação, mais do que por uma percepção singular (Leibniz definia a substância como a lei de desenvolvimento de uma tal série de percepções, série que ele interpretava como o desenvolvimento sucessivo dos predicados inerentes a um mesmo sujeito). É portanto um sistema de retas, mais do que um conjunto de pontos, que o universo das substâncias representa (ver a Fig. 1c, onde A e D aparecem como dois estados sucessivos da mesma substância I, que interage com as substâncias II e III pelas cadeias de ação ABD e ACD).

Figura 1c: Estrutura de substância

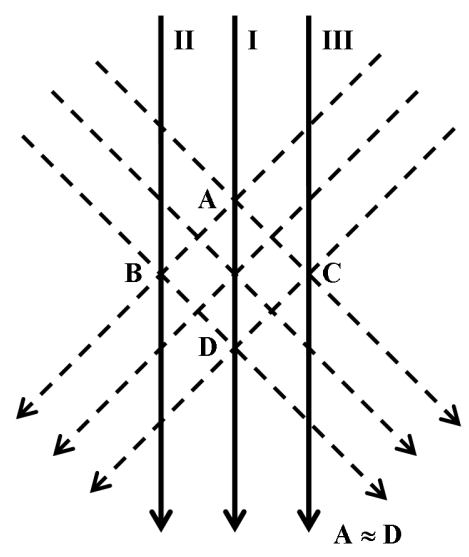


Em termos de parentesco, dir-se-á que a definição das substâncias equi-

vale àquela de uma regra de filiação unilinear. Se uma tal regra é dada (e apenas nesse caso) é possível considerar toda ação (além das interações simultâneas) como uma interação diferida entre sujeitos que persistem no tempo - dito de outra forma, como uma "troca". É pois importante ter em mente que uma estrutura de substâncias é uma especificação de uma estrutura espaço-temporal, da mesma maneira que esta última é, por sua vez, uma especificação de uma estrutura espacial. Se toda estrutura de troca é um espaço, o inverso não é verdadeiro.

\section{Significação cognitiva dessa estrutura}

Após ter discutido as propriedades formais do tipo de estrutura qualificada de "espaço", voltemo-nos para a questão de saber o que essas propriedades significam para uma estrutura de percepções mútuas.

A primeira qualidade fundamental de um espaço é sua homogeneidade: todas as posições são estruturalmente equivalentes, e nenhum indivíduo pode ser caracterizado por sua posição absoluta (quer dizer, pelo conjunto das posições nas quais ele aparece de todos os pontos de vista possíveis). Assim, o espaço se revela com " pura forma" da percepção, que pode receber qualquer conteúdo. De outro lado, o espaço tem também a qualidade de um principium individuationis: nenhuma posição se liga a duas outras da mesma maneira, e cada indivíduo pode ser completamente caracterizado por sua posição relativa (quer dizer, pela posição na qual ele aparece de um ponto de vista determinado). Essa dupla qualidade faz do espaço a imagem do grupo de suas próprias permutações, e torna cada percepção um verdadeiro espelho do universo: pois não somente seus elementos representam os sujeitos de todas as percepções alternativas, como também as relações entre esses elementos representam as relações entre esses sujeitos, quer dizer, as permutações mútuas de suas percepções. É esta "harmonia" entre o interior e o exterior que Leibniz havia sublinhado como traço estrutural fundamental da arquitetura da criação.

Consideremos as implicações cognitivas de uma tal arquitetura. De saída, o fato de que todo sujeito pode considerar a percepção de qualquer outro como uma permutação da sua própria percepção é, evidentemente, uma condição para um conhecimento objetivo do mundo. Para poder completar minha imagem de um objeto pela imagem que um outro sujeito tem do mesmo objeto, não é suficiente conhecer esta imagem, é preciso também compreendê-la, quer dizer, saber a que imagem ela corresponde em minha própria percepção. Tomemos um exemplo referente ao mundo social. Para completar meu 
conhecimento de meu pai com o testemunho de uma outra pessoa que o conhece, não basta que esta pessoa me descreva a natureza de suas relações com ele; é preciso também saber se eu devo compará-las com as relações que entretenho com meu irmão ou, antes, com aquelas que entretenho com meu cunhado - o mesmo comportamento pode representar uma brincadeira em um caso, um insulto no outro. Ora, se o conhecimento da posição da testemunha - por exemplo, aquela de um tio materno - basta, por si mesmo, para estabelecer uma correspondência única entre suas percepções e as minhas, dir-se-á que o conjunto de posições — pai, irmão, cunhado etc — exibe a estrutura de um espaço. Se, pelo contrário, o tio materno pode livremente considerar meu pai tanto um cunhado quanto um irmão (por exemplo, porque meu pai se casou com a própria irmã), essa inferência direta da posição relativa para a permutação de perspectivas não seria mais possível, e o conjunto das permutações, mesmo que estas constituíssem um grupo, não exibiria mais a regularidade constitutiva de uma estrutura espacial.

O valor cognitivo de uma estrutura espacial reside pois em sua função de instrumento na objetivação da experiência. Ela permite adotar o ponto de vista de todo e qualquer sujeito apoiando-se inteiramente sobre a maneira como este é percebido enquanto objeto, graças a uma correspondência unívoca das relações entre os objetos — quer dizer, de suas posições relativas com as relações entre sujeitos - quer dizer, com as permutações de suas percepções. Em uma linguagem metafísica, dir-se-ia que esta arquitetura "harmônica" da criação permite a toda criatura ultrapassar os limites de sua subjetividade e participar do conhecimento infinito do criador.

Mas o objetivo aqui não é nos aventurarmos na filosofia da natureza. Quero mostrar que essa mesma arquitetura caracteriza também certos universos criados pelo homem, e que, neste caso, trata-se não apenas de tornar possível o conhecimento de um mundo objetivo, mas sua própria criação. Com efeito, a correspondência entre as posições sociais dos sujeitos e as permutações de suas percepções exprime menos um fato que uma norma. Se, portanto, a perspectiva adotada por um sujeito não corresponde à posição simbólica que lhe foi atribuída, esta divergência não indicaria tanto um erro teórico, que exigiria corrigir o sistema simbólico - um pouco como as anomalias da experiência física tornaram necessário o abandono da geometria euclidiana -, mas, antes, um erro moral, que exigiria corrigir os sujeitos cujos comportamentos violam as expectativas dos demais².

Nada impede imaginar que uma tal estrutura possa emergir de modo "natural" como estado de equilíbrio ao fim de um processo de ajustamento recíproco das atitudes, quando cada sujeito terá finalmente tomado sua posição social em um espaço comum. Mas não parece existir nenhuma sociedade 
que não tenha procurado construí-la, ou pelo menos mantê-la, atribuindo aos sujeitos suas posições relativas de maneira mecânica, segundo critérios exógenos, independentes de suas ações, e publicamente acessíveis. O mecanismo mais disseminado de construção de um tal espaço social é o parentesco.

\section{Aplicação à teoria do parentesco}

Um sistema de parentesco é um sistema de percepções mútuas tal que a posição que um indivíduo atribui a outro depende do laço genealógico entre eles. Se ela depende unicamente deste laço, diremos que a estrutura de parentesco é elementar; se esta última condição não é satisfeita senão para certas posições, chamaremo-la semi-complexa; se, finalmente, o laço genealógico não é nunca suficiente para definir a posição social, chamaremo-la uma estrutura complexa ${ }^{3}$.

Vê-se bem quais são as propriedades formais que predestinam os laços genealógicos a compor uma estrutura espacial. De início, as duas relações de base das quais derivam (por inversão e composição) todas as outras, a saber, a relação paternal e a relação maternal, constituem já relações unívocas e em toda parte definidas ("aplicações", em termos matemáticos): cada indivíduo tem exatamente um pai e uma mãe. Ora, para fazer delas permutações, é preciso que o mesmo seja verdade de seu inverso, o que é evidentemente impossível enquanto seu domínio de definição for um conjunto de indivíduos - nenhum indivíduo pode ser mãe e pai ao mesmo tempo. A formação de um espaço de parentesco exige pois, forçosamente, uma interpretação classificatória do parentesco, que implica uma neutralização do sexo, quer dizer, a definição de uma relação de equivalência sobre o conjunto de indivíduos que reagrupe em uma mesma classe indivíduos de sexo diferente - por exemplo, tratando como idênticos todos os indivíduos que têm o mesmo vínculo genealógico a um terceiro (o que Radcliffe-Brown chamou de "unidade do grupo de germanos"). Os laços genealógicos definidos sobre o conjunto de classes de equivalência (tais como "grupos de germanos") satisfarão assim mais facilmente o critério das permutações: basta que cada classe contenha pelo menos uma mãe e um pai (em relação a qualquer membro de uma outra classe).

Enfim, para que o conjunto das permutações forme um grupo, é preciso que os laços de parentesco entre duas classes sejam completamente determinados pelos laços que elas entretêm com qualquer outra terceira classe. O que implica, em particular, que o laço matrimonial entre duas classes 
possa sempre ser definido em termos de seus laços genealógicos com as classes de seus ascendentes - dito de outro modo, que o casamento seja prescrito entre certos parentes. Em suma, para que uma rede genealógica forme um espaço em si (o que a caracteriza como uma estrutura elementar de parentesco) é necessário e suficiente que se trate de um sistema de parentesco classificatório com uma regra de casamento positiva e única. Este resultado é bem conhecido desde os anos 1970.

Ora, nada obriga supor que a rede genealógica seja a única base, ou mesmo a principal base, do espaço social que é o parentesco. De fato, em lugar de supor que os seres humanos derivaram suas posições sociais de suas relações genealógicas, parece bem mais razoável pensar que eles as tenham definido em conformidade com suas posições no espaço-tempo físico, e que as relações genealógicas não entram aqui senão indiretamente, devido ao fato de o nascimento e o casamento serem os principais determinantes da residência. Reformulemos pois nosso modelo de parentesco classificatório definindo as classes pela co-residência de seus membros, as relações entre as classes por suas relações espaço-temporais (enquanto sucessores ou predecessores, vizinhos da esquerda ou da direita etc.), e suponhamos que cada relação espaço-temporal implique uma relação genealógica qualquer: reside-se com consangüíneos e casa-se com vizinhos (notar-se-á a dificuldade lógica posta pelo fato de que o casamento implica igualmente uma forma de co-residência, mesmo que temporária. Essa dificuldade pertence ao sistema: ela desempenhará um papel fundamental na emergência das diferentes estruturas de parentesco de que trataremos na terceira seção.)

A conseqüência imediata de uma tal ampliação do código genealógico pelo código residencial é evidente: o número das permutações geratrizes não estando mais limitado a dois, o espaço de parentesco que elas engendram pode compreender um número muito mais elevado de alianças para cada grupo residencial, sem que as relações de parentesco assim especificadas percam a univocidade necessária para que se possa considerá-las permutações. Ali onde uma estrutura elementar não conhece senão uma "esposa", uma estrutura assim ampliada pode distinguir uma "esposa de cima" de uma "esposa de baixo", uma "esposa de longe" e uma "esposa de perto" etc., e, em lugar de limitar os casamentos aos indivíduos em uma posição genealógica determinada, as regras matrimoniais tenderão a espalhá-los sobre todo um conjunto de vizinhos, e mesmo a interditar todos os redobramentos de aliança até que todas as posições vizinhas tenham sido utilizadas (procedimento negativo que é, com efeito, um traço freqüente de estruturas complexas ou semi-complexas). 
Se essas pressuposições são válidas, e se a estrutura de parentesco é assim ancorada na estrutura do espaço residencial, deve ser possível observar correlações sistemáticas entre o sistema matrimonial e a morfologia do hábitat. Na próxima seção, examinarei esta questão a partir de casos empíricos tomados de quatro diferentes regiões do mundo. Em seguida, tentarei extrair algumas conclusões gerais e isolar os principais fatores que parecem determinar a estrutura particular do espaço que um grupo humano escolhe como forma extensiva de seu universo social.

\section{Inspeção dos dados etnográficos}

Apenas um estudo comparativo de variações entre sociedades vizinhas pode identificar as correlações existentes entre seu regime matrimonial e sua morfologia residencial; como os limites de espaço aqui não nos permitem uma análise explícita dessas variações, esta seção representa forçosamente um compromisso. Sem poder proceder a uma verdadeira análise transformacional, não quero entretanto me limitar a ilustrar o elo entre casamento e residência por meio de exemplos isolados, que não poderiam mostrar senão a coexistência de certos traços estruturais, enquanto o importante é a sua covariância. Selecionei portanto quatro pequenos grupos de sociedades, constituindo cada um uma área cultural e geográfica suficientemente separada das demais para permitir uma comparação entre casos adjacentes, mas evitando um viés regional.

A Figura 2 mostra a posição geográfica das sociedades abordadas; a Figura 3 fornece uma representação esquemática de sua morfologia espacial. É preciso sublinhar que estes esquemas não são mapas, mas diagramas; eles representam apenas as propriedades estruturais que quero comparar, e fazem abstração de todas as outras (como a forma geométrica e sobretudo a escala). As áreas sombreadas marcam as zonas "masculinas" nos espaços sexualmente divididos. 
Fig. 2: Localização geográfica das sociedades examinadas

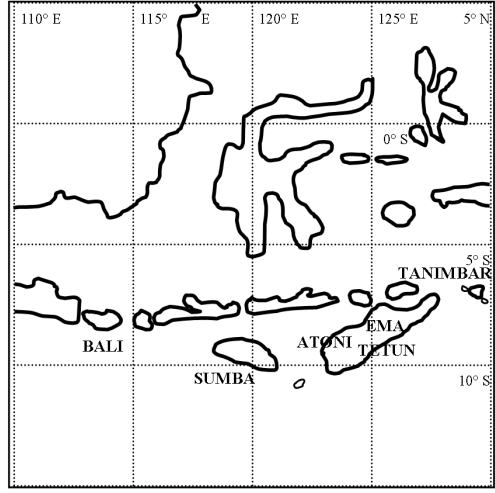

Indonésia Oriental

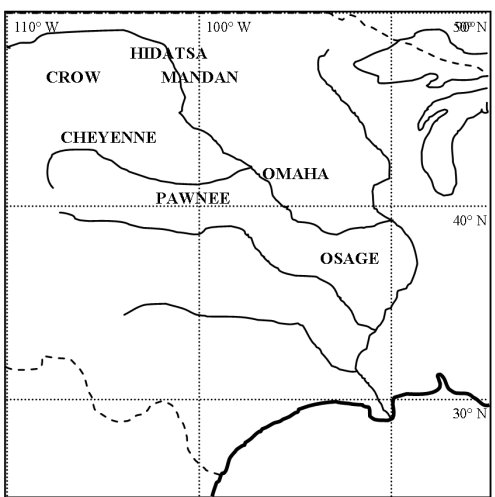

Vale do Missouri

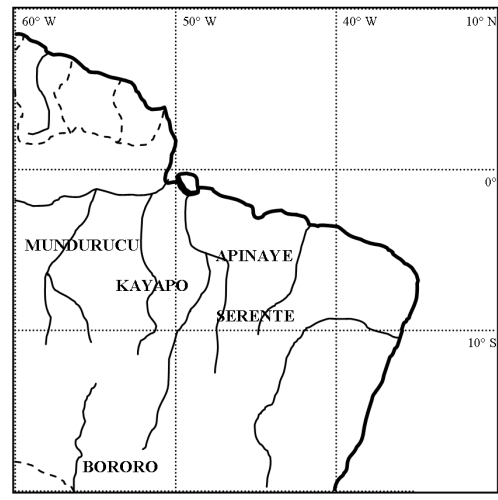

\section{Brasil Central}

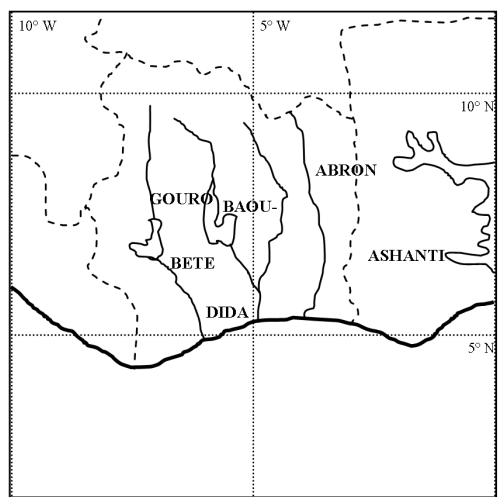

Costa da Guiné 
Fig. 3: Morfologias esquemáticas das sociedades examinadas
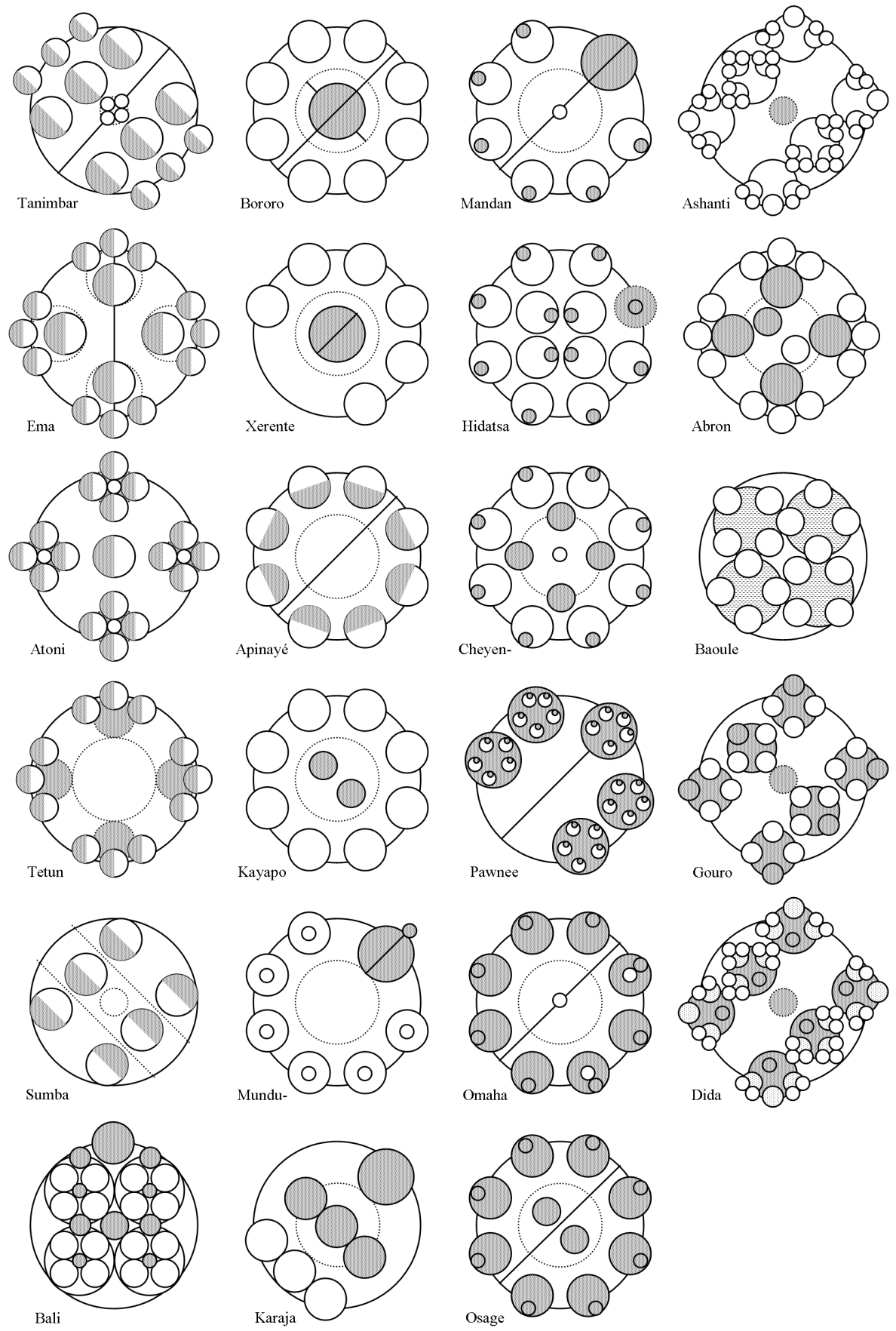


\section{Exemplo 1: Indonésia oriental}

Tanimbar. A aldeia tanimbar - compacta e, outrora, fortificada - é dividida em duas por uma estrada central que leva do mar ao interior. As casas retangulares (rahan) são voltadas para esta estrada central e se alinham a ela em várias fileiras paralelas. No centro, encontra-se uma praça pública com um barco cerimonial, feito de quatro bancos de pedra (dois no centro, um na proa e um na popa), que simbolizam a unidade da aldeia. As casas se agrupam em vários setores (arun), divididos por seu turno em diversos complexos de casas (rahan ralan) em torno de um núcleo de "casas nomeadas". Os laços matrimoniais são concebidos como "caminhos" entre as casas dos doadores (dua, "mestre") e as dos tomadores (uranak, "filho de irmã"). Os caminhos permanentes entre as casas nomeadas, que resultam de alianças matrimoniais unilaterais repetidas por muitas gerações — por meio do casamento com a prima cruzada matrilateral - formam "fileiras" (lolat) que pertencem ao patrimônio imóvel das casas participantes. Enfim, uma "grande fileira" conecta as quatro "casas-tronco" de uma ilha inteira em um ciclo fechado. A residência pós-marital é de início uxorilocal - a nova família constitui uma parte "feminina" da casa dos doadores - e a integração do homem, de sua mulher e finalmente de seus filhos em sua casa de origem procede por etapas, segundo o pagamento do dote. Por dentro, cada casa é dividida em dois lados por um eixo que leva da porta ao altar ancestral (tavu), o qual serve igualmente de poste central: o fogo doméstico se encontra do lado da terra, e a "plataforma principal" para a recepção dos visitantes (dedan ulu), do lado do mar. As demais plataformas em torno do perímetro servem para os casais, enquanto as moças solteiras dormem atrás do altar (McKinnon 1991; 1995; 2000).

Ema. O hábitat dos Ema - compacto ou disperso (não há conceito de aldeia) - consiste em vários complexos de casas quadrangulares (ume), sem unidade central, cada complexo estando agrupado em torno de uma "casa sagrada" (umar no apir), construída no terreno ritual na aldeia e voltada para o poente. Cada casa sagrada está ligada (por aliança matrimonial) a várias casas de doadores (uma mane, "casas masculinas") e de tomadores (mane heu, "novos homens"), das quais duas (em cada sentido) representam os parceiros originais (ei mea). Os laços, perpetuados pelo casamento com a prima cruzada matrilateral, formam idealmente ciclos de quatro elementos, que podem ainda ser reduzidos a ciclos mínimos (isto é, a relações de troca simétrica) pela possibilidade de esposar uma mulher proveniente dos doadores dos doadores, que tenha sido "adotada" pela casa dos doadores (casamento bei bei) — em um sistema quadripartite, 
os doadores dos doadores são simultaneamente os tomadores dos tomadores. Essa organização é compatível com uma organização tripartite da aldeia em duas metades e um centro - conforme o modelo do barco cerimonial de Tanimbar - de maneira que a troca entre as casas das duas metades passa pela intermediação das casas centrais (no caso, as casas de chefes). A residência é virilocal, mas a possibilidade de uma devolução da esposa ou de uma partilha das crianças depende do montante do dote. Por dentro, cada casa é dividida em uma "grande plataforma", à esquerda da porta (vista do interior), e uma "pequena plataforma" à direita (na verdade, trata-se de duas partes de uma mesma plataforma separadas por uma trave). A primeira, concebida como representando o lado masculino, compreende o patrimônio ancestral e serve a fins rituais; a segunda, concebida como representando o lado feminino, comprende o fogo doméstico e serve a fins profanos (Clamagirand 1975 [apud Waterson 1991]; 1980).

Atoni. A aldeia atoni (ou o distrito, conforme a tradução da palavra negeri), consiste em quatro aglomerados de casas (kuan), incluindo algumas vezes um quinto em posição central. Cada aglomerado compreende várias casas quadrangulares (ume) cuja unidade pode ser simbolizada por um celeiro comunal (lopo), erigido com quatro esteios e mais um "esteio materno" no centro. Cada casamento cria um "caminho" (lahan) entre a casa dos doadores (atoni amaf, "pais masculinos") e a casa dos tomadores (feto, "mulheres"). Os caminhos são perpetuados — sem inversão possível de direção - por meio do casamento com a prima cruzada matrilateral, e se fecham idealmente em círculos de quatro elementos (a terminologia de parentesco indicaria entretanto uma possibilidade de troca bilateral). A residência segue os mesmos princípios que em Tanimbar — inicialmente uxorilocal, ela só se torna virilocal com o pagamento completo do dote, as famílias uxorilocais constituindo "casas femininas" no aglomerado dos doadores. Em todo caso, pelo menos uma das crianças permanece sempre com seus tios maternos. Por dentro, cada casa se divide em um lado "masculino" (à direita da porta vista do interior, conceitualizado como o "sul" da casa, embora, objetivamente, esteja a leste) e um lado "feminino" (à esquerda e ao "norte", isto é, a oeste). A primeira compreende a "grande plataforma", reservada para os visitantes; a segunda compreende o fogo doméstico e a "plataforma de dormir", onde deita-se o casal. Aplicada à seção externa da casa (ziu), diante da porta, esta mesma dicotomia separa estritamente o lugar dos doadores (lado "masculino") daquele dos tomadores (lado "feminino"). Além disso, ela é posta em paralelo com a dicotomia entre o interior (nanan) e o exterior (mone) da casa, de maneira que a oposição entre mulheres e homens (e ainda entre doadores e tomadores) apare- 
ce como análoga àquela entre moradores (consangüíneos) e visitantes (aliados). Com efeito, o "poste maternal" que leva ao ático, onde se encontra o patrimônio ancestral, encontra-se no lado feminino (Cunningham 1964, 1967, Schulte-Nordholt 1971, 1980).

Tetun meridionais. A aldeia tetun consiste em complexos de casas quadrangulares (uma) arranjadas em círculo em torno de uma praça pública central. Cada casa possui uma porta dianteira que leva a uma plataforma exterior, e uma porta lateral que se abre para o poente. As casas se ligam por alianças matrimoniais repetidas de geração a geração, entre os mesmos parceiros (uma no tanasak, "casas dos [que trocaram] cestos"). Sendo a residência uxorilocal, não existe sistema de dote; todavia, como entre os Atoni ou os Tetun setentrionais, que praticam igualmente a aliança assimétrica entre doadores (umah maneh, "casa masculina") e tomadores (fetto sawa, "cintura de mulher"), a casa dos tomadores (no caso, tomadores de homens) entrega pelo menos uma criança à casa dos doadores. Idealmente, trata-se de uma filha (mata nusan), que irá se casar na casa de suas tias paternas - resultando em um casamento com a prima cruzada matrilateral - e que por sua vez entregará uma filha (ramas abut) à sua própria casa de origem. Em cada casa, a parte interior (laran) pertence às mulheres, a plataforma exterior (lor) aos homens; um eixo leste/oeste divide ambas em dois lados que, no exterior, corrrespondem respectivamente ao lugar dos maridos e àquele dos irmãos (logo, ao dos tomadores e ao dos doadores de mulheres nos termos de um sistema virilocal). Ao mesmo tempo, a dicotomia entre poente e nascente é posta em paralelo - sobre o fundo de uma oposição entre escuro e claro - com aquela entre interior e exterior, do que resultam as mesmas associações (entre maridos e mulheres de um lado, irmãos e homens de outro) que no caso dos sistemas em que se pratica troca de mulheres no sentido estrito (Van Wouden 1935; Francillon 1968; 1989).

Sumba oriental. A aldeia de Sumba é atravessada por uma rua central segundo um eixo paralelo a um rio. As casas retangulares são voltadas para essa rua, as mais antigas situando-se a oeste (viradas para o nascente), as mais recentes a leste. A esta divisão junta-se uma organização tripartite em uma parte a montante, que forma a "cabeça" da aldeia, uma parte a jusante, que forma sua "cauda", e uma parte central, onde fica a praça pública. As partes extremas compreendem as casas nobres que governam a aldeia (marimba) as de rio acima sendo superiores às de rio abaixo - enquanto que a parte central abriga as casas das autoridades religiosas (ratu), superiores aos nobres. As casas - sobretudo as casas nobres - são ligadas por alianças matrimoniais assimétricas, perpetuadas pelo casamento prescritivo com a prima 
cruzada matrilateral (em particular, a casa que governa a metade superior dá mulheres à casa que governa a metade inferior), embora não se busque a formação de ciclos. A residência segue o modelo habitual de um processo gradual em direção à virilocalidade. Por dentro, cada casa é dividida em um "grande piso" (kaheli bokulu) à direita da porta (vista do interior) e um "piso frio" à esquerda, o primeiro constituindo o lado masculino e cerimonial, o segundo o lado feminino e doméstico (o lado direito só é acessível a uma mulher após o pagamento completo do dote). A mesma dicotomia se aplica às partes frontal e posterior da casa, que (à diferença do caso atoni) são conceitualizadas como "interior" e "exterior" segundo sua distância do centro da aldeia (Needham 1980; Adams 1980; Forth 1981).

Bali. O aglomerado balinês (bandjar) se apresenta como uma densa grade de pátios fechados, cada pátio reunindo um templo doméstico (voltado para a montanha sagrada), uma ou várias casas familiares (uma meten) que abrigam as famílias residentes, assim como, para cada família, um pavilhão aberto (bale) que serve como ateliê cotidiano e dormitório para os solteiros, uma cozinha (paon) e um celeiro de arroz (lumbung) casas, pavilhões e cozinhas estando freqüentemente dispostas em linhas paralelas. Todas as famílias de um pátio, embora ligados ao mesmo templo ancestral, constituem unidades autônomas separadamente representadas no conselho do aglomerado. Inversamente, a segmentação de um pátio não destrói os laços ao templo do pátio de origem, que permanece o templo de referência (sanggah gde, "grande templo") para todos os pátios dele derivados, e cuja transferência para o espaço público confirma a constituição oficial do conjunto como pessoa moral (dadia). Cada dadia pode, por sua vez, segmentar-se em várias sub-dadias (paibon, "da mesma mulher"), do mesmo modo que o aglomerado inteiro pode ser considerado como uma grande dadia cujo sanggah gde seria o templo de todos os ancestrais fundadores (pura puseh), e cujo bale seria a casa do conselho (bale badjar). O traço característico da estrutura do aglomerado é pois a isomorfia com cada uma de suas partes componentes, até o nível do pátio familiar. Ora, se o aglomerado pode se conceber como um grande pátio, o inverso é igualmente verdade. Cada pátio, e em todo caso cada dadia, constitui uma unidade idealmente autárquica, sobretudo em termos matrimoniais: os aliados ideais são as casas do mesmo pátio, isto é - dada a residência patrilocal — os primos paralelos patrilaterais. Isso implica que as mulheres de um mesmo pátio sejam, idealmente, parentas agnáticas - condição que, na ausência de um casamento no grupo paterno, pode ser igualmente mantida pelo redobramento dos casamentos de germanos de mesmo sexo, enquanto que o redobramento do casamento de ger- 
manos de sexo oposto ("troca de irmãs") é evitado. Essas indicações convidam a considerar o "casamento árabe" em Bali como uma transformação da troca generalizada, da qual ele conserva o princípio maior - todas as esposas do grupo pertencem a um só grupo - violando um outro - o grupo das esposas e o grupo dos maridos deixam de ser distintos. A conseqüência é o apagamento de todo dualismo sexual na organização da casa e uma isomorfia real entre a casa e a aldeia enquanto espaços homogêneos (Geertz 1964; Geertz e Geertz 1975).

\section{Resumo}

Ao longo dessas transformações, podem-se reter como traços invariantes:

- a associação entre troca generalizada e uma divisão longitudinal de cada casa pelo eixo central fixado pela porta, atribuindo-se os lados direito e esquerdo, respectivamente, aos sexos masculino e feminino, assim como aos doadores e tomadores de esposa na troca de mulheres;

- a superposição a essa divisão de uma segunda, desta vez transversal, entre uma parte frontal ou exterior e uma parte posterior ou interior, divisão que corresponde ao dualismo entre o centro e a periferia da aldeia, e que parece tanto mais marcada quanto o hábitat é concentrado; ela pode igualmente associar-se à divisão sexual, mas não àquela entre doadores e tomadores;

- o fato de que o caráter uxorilocal ou virilocal da residência (diríamos mais precisamente: a velocidade da transição da uxori- à virilocalidade) não afeta as propriedades estruturais do espaço, salvo, talvez, pelo fato de que a uxorilocalidade parece implicar uma maior concentração do hábitat (e, conseqüentemente, uma divisão "transversal" mais marcada das casas).

\section{Exemplo 2: o Brasil central}

Bororo. A aldeia bororo consiste em várias casas coletivas, retangulares, arranjadas em um círculo (ou vários círculos concêntricos) em torno de uma praça central, para a qual estão voltadas suas portas principais (no meio da parede longa); as portas traseiras levam à floresta. Cada mulher casada possui um fogo doméstico próprio, ao longo do eixo longitudinal da casa. No centro da praça, encontra-se a casa-dos-homens (baito), construída da mesma forma que as casas periféricas, com as laterais longas orientadas segundo um eixo leste-oeste. Ela serve como santuário, ateliê e dormitório. A aldeia, a praça central e a casa-dos-homens são divididas em um lado oeste (concebido como esfera sagrada) e um lado leste (concebido como esfera profana). 
No interior do baito, os homens se agrupam segundo sua casa de origem, sem que a estrutura interna se torne por isso isomorfa àquela da aldeia: embora a organização em metades permaneça invariante (com inversão de direção, de modo que as metades dos homens são contíguas às metades de suas possíveis esposas), as casas dos dois chefes de cada metade - posições vizinhas no centro do baito - são contíguas apenas no caso da metade sul (onde ocupam o centro), enquanto que, na metade norte, eles ocupam as posições extremas no leste e no oeste. O dualismo norte/sul aproxima-se assim de um dualismo centro/periferia, que conota não apenas a dicotomia dos sexos, mas também um dualismo etário (os primeiros chefes do norte são pais dos primeiros chefes do sul). A residência pós-marital é uxorilocal; entretanto, considerando que os homens residem, a partir de sua iniciação, junto a seus parentes uterinos masculinos na casa-dos-homens, que permanece o centro de suas atividades mesmo após o casamento, a residência masculina seria melhor caracterizada como "avunculocal". As alianças entre as casas - representadas por uma rede de "caminhos" (utawara) — são conceitualizadas menos como laços matrimoniais enquanto tais que como vínculos entre os homens e seus padrinhos de iniciação (iorubadare, "dono do meu fogo doméstico"). Estes últimos correspondem, contudo, aos primeiros, pois o iorubadare é, ao mesmo tempo, parente uterino do pai (sobrinho uterino ou irmão mais novo) e cunhado preferencial. Esse ideal implica uma preferência pelo casamento com a prima cruzada patrilateral ou com a tia paterna, o que se reflete também na terminologia. Segundo Lévi-Strauss, essa regra matrimonial é ainda especificada pela divisão dos matriclãs em três grupos supostamente endógamos - de cima ou montante, do meio, de baixo ou jusante - segundo a direção leste-oeste dos rios (Lévi-Strauss 1936; 1958 [1952]; 1958 [1956]a; Colbacchini 1996 [1942]; Crocker 1979; Fabian 1992).

Xerente. A aldeia xerente consiste em casas circulares (abrigando famílias nucleares) arranjadas em semi-círculo em torno de uma praça central onde se encontra a casa-dos-homens, igualmente redonda. No interior desta última, os homens agrupam-se em quatro setores, segundo a sociedade cerimonial a que pertencem; um eixo leste-oeste divide a casa-dos-homens (bem como cada setor) em duas metades, norte e sul respectivamente. A afiliação às metades é transmitida em linha agnática, o padrinho de iniciação sendo idealmente o tio paterno, enquanto que o pertencimento a uma sociedade é determinada pelo pai, que em geral seleciona uma sociedade diferente da sua própria. No que diz respeito à organização social da periferia, os testemunhos etnográficos oferecem uma imagem contraditória: as fontes antigas aplicam aí a mesma divisão em metades agnáticas que governa a organização do centro, cada metade segmentando-se em quatro patriclãs localizados. Essa organização é, entre- 
tanto, incompatível com a residência uxorilocal atestada pelas fontes mais recentes; de fato, ela aparece mais como projeção ideológica da organização do centro sobre aquela da periferia (com a reserva, notadamente, de que os quatro segmentos de cada metade central não são tampouco patrilocais). O desejo de minimizar tanto quanto possível essa contradição entre um modelo virilocal e uma realidade uxorilocal pode, todavia, explicar certos traços característicos do sistema matrimonial, tais como a prática de redobramento de casamentos por germanos de mesmo sexo (o que preserva a co-residência dos parentes agnáticos de mesma geração) ou o casamento preferencial com a prima cruzada patrilateral (que preserva a co-residência dos parentes agnáticos de gerações alternas) (Lowie 1963; Maybury-Lewis 1967; 1979).

Apinajé. A aldeia apinajé se apresenta como um círculo de casas coletivas retangulares em torno de uma praça pública (ingo) que serve para as reuniões masculinas, sem ser porém ocupada por uma casa-dos-homens. Cada casa é dividida em uma parte dianteira, associada à praça central e à vida pública masculina, e uma parte traseira, compreendendo os compartimentos fechados das famílias, associada à esfera feminina e à floresta periférica, à qual se conecta pela porta dos fundos. A praça central divide-se temporariamente em duas metades cerimoniais, do leste e do oeste (concebidas como lados masculino e feminino, respectivamente), às quais a afiliação é transmitida, juntamente com os nomes pessoais, em linha uterina para os homens e em linha agnática para as mulheres. A isso se adiciona um segundo par de metades cerimoniais, desta vez associado à dicotomia centro/periferia, mas sempre posto em paralelo com o primeiro par pela associação, digna de nota (e conscientemente percebida como uma inversão), do centro com o lado feminino. A afiliação a este segundo par de metades é transmitida pelos "amigos formais" (kra-geti e pakra), padrinhos de iniciação, que são por sua vez escolhidos (como aliás os nominadores) pelos "pais adotivos" (pam kaag e na kaag), idealmente, entre os filhos adotivos de seus próprios "amigos formais". Como a filha do "amigo formal" é chamada "esposa" (sem ser realmente uma, como seria o caso nos Bororo), esta última regra engendra uma estrutura de parentesco que, mesmo que perfeitamente simbólica e ritual, seria isomorfa à estrutura engendrada pelo casamento com a prima cruzada matrilateral. Com efeito, nenhum dos pares de metades determina o casamento. Todavia, o fato de que o amigo formal, assim como a esposa e, portanto, necessariamente, o tio materno, são pensados como provenientes do outro lado da aldeia, permite concebê-las como virtualmente exógamas. A residência pós-marital é uxorilocal, e as casas são assim ligadas por uma rede bipolar subjacente à circulação dos homens assim como à circulação dos nomes femininos (DaMatta 1979; 1982). 
Kayapó. A aldeia kayapó é formada por casas coletivas retangulares (na verdade, ovais), dispostas em círculo em torno de uma praça central que abriga uma - ou, segundo fontes mais antigas, duas - casa(s)-dos-homens (ngobe). Cada casa da periferia é dividida em setores familiares sem separação, mas dotado cada um de sua própria porta para o centro. A praça central divide-se em metades cerimoniais leste e oeste, cada uma com sua própria casa-dos-homens e seu próprio chefe. Ao contrário do que ocorre com a transmissão dos nomes próprios, que se faz, como entre os Apinajé, em linha cruzada, a afiliação às metades é transmitida em linha paralela por pais substitutos, as mulheres casadas juntando-se à metade de seus maridos. Dir-se-á pois que a residência cerimonial é "patri-virilocal", mas, entenda-se, apenas em termos puramente simbólicos, uma vez que o pai substituto não mantém com o filho nenhuma relação de parentesco real. Todavia, a terminologia de parentesco parece refletir esse parentesco cerimonial, já que apresenta traços "omaha" lá onde a terminologia apinajé exibe traços "crow". Não obstante, o ofício de líder das metades se transmite em linha uterina, conforme a localização fixa das casas familiares dos dois chefes em posições simétricas no leste e oeste da aldeia, e a residência real é uxorilocal. Observamos, portanto, as mesmas contradições que no caso dos Xerente, contradições que os Kayapó não parecem, porém, resolver por intermédio de estratégias matrimoniais, mas sim pela distinção entre um parentesco cerimonial (agnático), que rege o centro, e um parentesco biológico (uterino), que rege a periferia (Dreyfus 1963; Turner 1979).

Munduruku. A aldeia munduruku consiste em casas coletivas ovais dispostas em torno de uma praça central, cada casa compreendendo tantos fogos domésticos quantas são as famílias nucleares (que não são separadas em compartimentos) e um fogo coletivo para a mandioca no meio, que constitui o centro da vida feminina. Uma porta "feminina" abre-se para a floresta, uma porta "masculina" para a praça pública. No oeste (ou, alternativamente, no centro) desta praça situa-se a casa-dos-homens (eksa), onde os homens passam a maior parte do dia (com efeito, eles só se dirigem à casa da esposa para o ato sexual, dormindo e alimentando-se na eksa). A casa-dos-homens é dividida em duas metades (norte e sul) que correspondem às metades patrilineares, e o pertencimento aos (cerca de) 40 patriclãs determina a localização precisa em cada metade e a ligação com as flautas sagradas que se encontram em um abrigo (kaduke) no sudoeste da eksa. Sendo a residência uxorilocal - o que implica freqüentemente o afastamento do homem de sua aldeia natal —, vê-se bem que a casa-dos-homens representa aqui a reprodução de um mesmo e único mundo masculino, ideologicamente autônomo e independente do meio físico (sempre feminino) no qual por acaso se mate- 
rializa (os mitos imaginam mesmo, inclusive, o ideal de uma reprodução sem mulheres). O problema posto pela coexistência de duas regras de residência incompatíveis é, pois, resolvido pela separação quase total do espaço feminino e do espaço masculino. Entretanto, a vontade de torná-los congruentes parece orientar as escolhas matrimoniais, tal como sugeridas pela terminologia: a saber, o casamento com a sobrinha uterina (que permite ao homem permanecer em sua casa natal) ou com a prima cruzada patrilateral (que lhe permite retornar à casa do pai) (Murphy 1954; 1960; Nadelson 1981).

Karajá. A aldeia karajá constitui-se de casas coletivas retangulares (com um fogo separado para cada mulher casada), alinhadas segundo um eixo norte-sul em uma ou várias fileiras paralelas nas margens de um rio para o qual estão voltadas. A leste, atrás das casas familiares, separada delas pela praça cerimonial, e ligada ao rio por um caminho próprio, encontra-se a casa-doshomens (idjato-heto), dormitório dos celibatários e santuário das máscaras rituais. Na praça cerimonial, em paralelo à linha das casas familiares, são construídas, durante o ritual principal (heto hyky, "casa grande"), três edificações temporárias: a "casa grande" (heto hyky), a montante, a "casa pequena" (heto riore), a jusante, e uma galeria intermediária (hererawo) entre elas, cada uma das quais abrigando um grupo de homens (wa-idjui). O pertencimento a esses grupos é transmitido por linha agnática, em oposição à residência normal, que é uxorilocal. A distância entre as duas residências de um homem é minimizada pela regra de casamento com as irmãs e filhas de homens do mesmo grupo cerimonial, de modo que as três casas rituais formam, com as partes adjacentes da fileira de casas familiares, outras tantas sociedades endógamas. Esta tripartição da sociedade karajá segundo o curso do rio é, pois, perfeitamente análoga àquela que Lévi-Strauss encontrou entre os Bororo, com a diferença importante de que ela não é coroada aqui por nenhuma organização em grupos exógamos, sendo o casamento indiferentemente autorizado com todos os primos, cruzados ou paralelos (com, todavia, uma clara preferência pelos cruzados e patrilaterais). Assim, o espaço karajá representa a solução mais extrema ao problema colocado por uma regra de residência dupla: uma estrutura residencial que não é mais isomorfa, mas complementar, à estrutura matrimonial (Lipkind 1963; Dietschy 1976; Pétesch 1992).

\section{Resumo}

Como traços invariantes, deve-se reter os seguintes:

- a coexistência entre duas regras de residência diferentes, uma para homens e outra para mulheres, associada a um aprofundamento da divisão 
entre centro (como espaço masculino) e periferia, bem como à abolição, que acompanha aquela da dicotomia entre tomadores e doadores, de qualquer divisão longitudinal no interior das casas familiares;

- a presença de várias estratégias para remediar a desarmonia entre a organização da periferia e a organização do centro, das quais as principais são: i) a separação máxima entre as duas esferas, seja fisicamente, minimizando a comunicação entre elas, seja simbolicamente, aplicando duas concepções diferentes (uma biológica, outra ritual) ao laço de parentesco; e ii) a minimização das divergências entre as duas estruturas por meio de um regime matrimonial apropriado: seja o redobramento dos casamentos de germanos de mesmo sexo, o casamento oblíquo, o casamento com a prima cruzada patrilateral ou - caso limite - o casamento no seio de um grupo de consangüíneos que elimina as divergências entre os dois espaços, privando-os de suas estruturas.

- a divisão diametral da aldeia em duas metades exógamas, cuja associação simbólica com a oposição entre centro e periferia (e portanto, indiretamente, homens e mulheres) evoca o modelo "indonésio", ainda que transposto aqui do nível local da casa para o nível global da aldeia.

\section{Exemplo 3: Vale do Missouri}

Mandan. A aldeia de verão dos Mandan é composta de numerosas casas de terra circulares e semi-subterrâneas, estreitamente agrupadas em torno de uma praça cerimonial central. No meio da praça encontra-se um poste de cedro, cercado por uma paliçada feita de troncos de choupo, que simboliza a unidade da aldeia e que é concebido, ao modo indonésio, como um barco. A casa cerimonial (casa okipa, assim chamada conforme o ritual principal) situa-se na margem setentrional da praça. Um eixo norte-sul que atravessa a casa cerimonial divide a aldeia em duas metades, das quais a metade oriental é associada à guerra e à agricultura, e a metade ocidental à paz e à caça. No interior, cada casa contém vários compartimentos arranjados, em torno de um único fogo central, dos dois lados de um altar que se encontra diante da porta e marca o lugar do chefe da casa. O estatuto de cada casa é determinado pela presença de pacotes cerimoniais tribais possuídos pelos homens da família, entre eles os pacotes associados aos chefes da guerra e da paz. Os pacotes mágicos são transmitidos, como as casas, em linha uterina. Sendo a residência pós-marital uxorilocal, o desejo de manter o estatuto da casa encoraja o casamento com a prima cruzada matrilateral, mas todos os casamentos entre membros de metades diferentes são autorizados. Se a 
casa familiar é o domínio das mulheres (tipicamente, várias irmãs casadas com o mesmo marido), a casa cerimonial é reservada aos homens, que ali se agrupam segundo seu pertencimento aos clãs uterinos. Em compensação, os nomes pessoais dependem do pacote cerimonial do padrinho, que, assim como o padrinho de iniciação à primeira sociedade masculina no sistema de classes de idade, pertence ao clã do pai. A relação com este "pai" ao mesmo tempo cerimonial e classificatório é ativada por ocasião de cada passagem de uma sociedade à outra, e o pertencimento a essas sociedades é transmitido de "pai" a "filho" por meio de um coito ritual do primeiro com a esposa do segundo (mulher que ele chama de "neta", conforme a terminologia crow aplicada a um sistema de troca generalizada) (Catlin, em Donaldson 1886 [apud Lévi-Strauss 1968:382], Bowers 1950; Wood e Irvine 2001).

Hidatsa e Crow. As casas hidatsa são construídas exatamente da mesma maneira que as dos Mandan, mas os traços característicos de suas aldeias de verão são diferentes: não há nem praça central, nem orientação das casas e, se as metades matrilineares se conservam, elas já não determinam os casamentos nem o agrupamento espacial (no caso dos Crow, parentes dos Hidatsa, elas desaparecem completamente). Além disso, o casamento com a prima cruzada matrilateral é desaprovado (Bowers nada diz sobre a prima cruzada patrilateral, mas sabemos que os Crow, interditando o casamento no matriclã da mãe, autorizam-no no matriclã do pai, com cujos membros mantêm-se relações jocosas). Enfim, a casa cerimonial permanente dos Mandan é substituída por uma casa cerimonial temporária (construída por ocasião do ritual do naxpike, que substitui o okipa mandan), construída em torno de um poste central de choupo, que já não serve aqui para comemorar a origem da tribo, mas sim para celebrar a transmissão de um pacote cerimonial tribal — transmissão que, diferentemente do que ocorre nos Mandan, se faz de pai para filho. Com efeito, essa mudança na linha de transmissão - que inclui a transmissão da chefia - e, conseqüentemente, a circulação dos pacotes cerimoniais entre as casas (onde são dispostos em face da porta), parece acarretar boa parte das transformações descritas: a casa cerimonial, nos Mandan uma casa-dos-homens, converte-se nos Hidatsa em uma espécie de residência patrilocal temporária - transformação que se completa nos Crow, onde a residência patrilocal (com abandono da aldeia pelo acampamento de caça) torna-se permanente, e onde a nora (chamada então "filha") reside com seu "pai" mesmo depois da cerimônia de iniciação por ela mediada (Bowers 1965; Stewart 2001; Lowie 1935; Voget 2001).

Cheyenne. O acampamento de inverno de um bando (manhao) cheyenne consiste de entre dois e sete grupos de tendas cônicas [tipis] familiares, todas orientadas para o levante e agrupadas em torno da tenda pintada do chefe. 
A estrutura interna da tenda - com um fogo central e um lugar de honra em face da porta - evoca, fortemente, aquela da casa de terra à moda mandan (que a precedeu), com uma exceção importante: a divisão - característica de todas as sociedades das planícies - entre uma metade "masculina" à esquerda da porta (vista de dentro) e uma metade "feminina" à direita. A consangüinidade sendo calculada cognaticamente, o casamento com todos os primos é interdito, e o bando é, portanto, praticamente exógamo, o que, somado à residência uxorilocal, produzia até os anos 1860 uma circulação de homens em toda a área tribal, em plena conformidade com a manutenção de uma densa rede comercial. Nesta época, a coabitação dos parentes paternos limitava-se ao período da Dança do Sol (equivalente ao naxpike hidatsa), quando o círculo tribal se formava em torno da "tenda xamânica" (mohaewas), e ao período guerreiro subseqüente - o pertencimento às sociedades militares sendo transmitido (assim como os nomes próprios) em linha agnática. $\mathrm{O}$ círculo tribal tem a forma de uma grande tenda, abrindo-se para o levante, na qual cada bando, agrupado em torno da tenda de seu chefe, ocupa uma posição determinada. As sociedades militares se constituem imediatamente antes da formação do círculo tribal, e constroem suas tendas nos quatro cantos do quadrado que enquadra virtualmente o círculo (nos Blackfoot, parentes setentrionais dos Cheyenne, elas formam um círculo interior). O círculo tribal se apresenta, portanto, ao mesmo tempo, como uma concentração de grupos dispersos em uma mesma estrutura espacial, e como uma superposição transitória de dois tipos de organização social - a primeira uterina, a segunda agnática — que se alternam com o ritmo sazonal da paz e da guerra. Essa periodicidade é abandonada nos anos 1860, quando os Cheyenne entram em um estado de guerra permanente, processo que se acompanha da absorção dos bandos pelas sociedades militares e da introdução da residência virilocal (Bushnell 1922; Forde 1950; Moore 1987; Moore et al. 2001).

Pawnee. As aldeias pawnee, não necessariamente descontínuas entre si, compõem-se de casas de terra dispersas, de construção similar à das casas mandan e hidatsa, com a diferença de que são uniformemente orientadas para o levante - direção associada à estrela da manhã e ao princípio masculino. Conseqüentemente, o altar retangular com o pacote sagrado, os lugares de honra e a área sagrada (que representa o acampamento tribal original, no céu) situam-se sempre a oeste, direção associada à estrela da tarde e ao princípio feminino. As casas são transmitidas em linha uterina, os pacotes sagrados (incluindo-se o pacote sagrado da aldeia, pertencente ao chefe) em linha agnática. O desejo de manter os pacotes cerimoniais no interior de um círculo estreito de casas (e sobretudo da aldeia) 
encoraja pois casamentos próximos, de preferência com "avós" classificatórios segundo a terminologia crow (isto é, entre certos filhos de primos), e com habitantes da mesma aldeia. Ora, a despeito desse isolamento mútuo em termos matrimoniais, as aldeias pawnee formam, em seu conjunto, uma estrutura altamente organizada. Essa estrutura se manifesta não somente na organização do acampamento tribal durante a caça cerimonial (equivalente do círculo tribal, que não existe entre os Pawnee), ou no arranjo dos assentos na casa do conselho e nas casas das sociedades masculinas (sempre inter-aldeãs), mas, sobretudo, na distribuição espacial das aldeias, que reproduz uma constelação celeste. Essa afiliação de cada aldeia a uma estrela, da qual deriva seu pacote sagrado, implica também uma organização em metades segundo a dicotomia norte/sul, dicotomia igualmente representada pelos dois lados de cada casa, e associada àquela entre inverno e verão. Enfim, embora não haja casamento propriamente dito entre casas de aldeias diferentes, sua função é cumprida por um ritual - o hako - que cria, igualmente, laços "paternos" entre elas (com efeito, trata-se de uma transformação direta do ritual de iniciação mandan, salvo que o pai cerimonial não é mais um pai classificatório, e que a função mediadora do filho passa de uma mulher a uma criança) (Murie 1989; Parks 2001; Fletcher 1904; Lévi-Strauss 1958 [1956]b).

Omaha. A aldeia omaha, composta de casas de terra, não exibe nenhum princípio de organização particular (como uma praça central ou uma divisão em metades), com exceção de uma orientação geral para o levante. Por outro lado, a rede de laços matrimoniais exibe uma estrutura complicada, engendrada por uma organização em dez patriclãs agrupados em duas metades, e um sistema de interditos que proíbe o casamento nos clãs de todos os avós, com exceção do da avó materna. A residência sendo uxorilocal, essa organização se manifesta na morfologia apenas na formação do círculo tribal (hucuga), por ocasião da caça coletiva, quando os habitantes da aldeia se agrupam segundo a afiliação clânica. Orientado para o leste (ou, mais geralmene, na direção da caminhada), o círculo tribal é dividido em uma metade esquerda, associada à paz, ao céu e ao sexo masculino, e uma metade direita, associada à guerra, à terra e ao sexo feminino - a tribo inteira sendo também denominada "os dois lados da casa". Esta estrutura evoca aquela da aldeia mandan, da qual reencontramos ainda o poste de cedro sagrado (sempre pertencente a um clã da metade "masculina"), mesmo que a unidade tribal seja aqui representada por um poste de choupo (pertencente a um outro clã da mesma metade; a cerimônia da dança do sol pertence a um terceiro clã). Entretanto, não se trata apenas de uma substituição de matriclãs por patriclãs - que poderíamos considerar, com Désveaux (2001), como sociedades 
militares transformadas - mas da introdução de um sistema de residência alternada, solução que, entre todos os sistemas desarmônicos até aqui discutidos, parece permitir uma maior multiplicação das alianças (Dorsey 1884; 1897; Fletcher e La Flesche 1911; Liberty et al. 2001).

Osage. A aldeia permanente dos Osage consiste em casas de entrecasca ou tendas retangulares (não tipis cônicos) dispostas dos dois lados de uma rua central que a atravessa de leste a oeste. Assim como no círculo tribal omaha, a metade setentrional da aldeia é associada à paz e ao céu, a metade sul à guerra e à terra. Cada metade possui seu próprio chefe hereditário (em linha paterna), cuja casa, que serve igualmente como santuário - com suas duas portas, leste e oeste, e um fogo no meio - situa-se no centro da aldeia, cercada pelas casas de dez guerreiros. As outras casas estão dispostas, segundo a afiliação clânica de seus membros masculinos, em uma estrutura isomorfa ao arranjo dos assentos durante a congregação cerimonial chamada "casa de mistério" (o arranjo cerimonial inverte, todavia, a direção leste-oeste por ocasião de uma cerimônia de paz, e a direção norte-sul por ocasião de uma cerimônia de guerra, como se cada cerimônia implicasse uma mudança de perspectiva). Ora, essa isomorfia atestada entre a disposição dos clãs de um lado, e das casas de outro lado, coloca um grave problema de interpretação diante do fato de que os clãs são patrilineares, enquanto que as fontes descrevem a residência como sendo uxorilocal. A única interpretação possível parece ser a suposição de uma dupla morfologia, a exemplo daquela dos Omaha que, como nos Osage, acompanha um sistema de alianças matrimoniais múltiplas nos quadros da exogamia das metades (os Osage interditam o casamento nos patriclãs dos quatro avós) (Bailey 1995; 2001).

\section{Resumo}

Cabe reter os mesmos traços principais que no Brasil Central, com as seguintes diferenças:

- aprofundamento da separação entre espaço central (virilocal) e espaço periférico (uxorilocal) por meio do emprego da dimensão temporal (dupla morfologia segundo uma alternância sazonal);

- tendência à multiplicação das alianças matrimoniais (por um sistema de interditos de redobramento) em correlação com esta alternância entre dois regimes de residência, enquanto as estratégias matrimoniais já evocadas, que permitem gerir o conflito entre esses dois regimes, permanecem em vigor lá onde a dupla morfologia é menos desenvolvida;

- introdução, nas casas da periferia, de um dualismo concêntrico local que su- 
prime, em uma certa medida, a divisão transversal (o centro local situando-se na parte interior), dualismo associado à dicotomia sexual, quer dizer, à oposição entre o marido e suas esposas (sobretudo nos quadros da poliginia sororal);

- por fim, a reaparição, nas casas virilocais, da divisão "indonésia" em lados masculino e feminino, nesse caso posta em paralelo com a divisão diametral da aldeia e do acampamento em metades exógamas.

\section{Exemplo 4: Costa da Guiné}

Axanti. A aldeia axanti consiste em grandes casas coletivas estreitamente agrupadas dos dois lados de uma rua central que faz as vezes de praça pública (as árvores aí plantadas representam os chefes da aldeia). As casas são conjuntos compostos de cabanas retangulares dispostas de maneira modular em torno de um ou vários pátios comunicantes, que podem atingir a dimensão de quarteirões inteiros. Os pátios internos são dominados pelas mulheres, que aí cozinham comunalmente, cada casa constituindo idealmente uma comunidade de comensalidade. As casas são mutuamente aliadas por casamentos continuamente redobrados de uma geração a outra (com a prima cruzada bilateral, com inflexão matrilateral), ao mesmo tempo em que o interdito sobre o redobramento de casamentos (por consangüíneos de mesmo sexo) na mesma geração assegura a multiplicidade das alianças. A residência pós-marital permanece natolocal para os dois sexos, e isso apesar de um ideal patrilocal expresso pelos homens, cujo espírito se transmite agnaticamente enquanto seus bens - esposas inclusive - são transmitidos em linha uterina. A circulação dos espíritos masculinos implicada por esse sistema é entretanto minimizada pela autorização do casamento com as primas cruzadas patrilaterais e pela endogamia de aldeia (Rattray 1929; Danquah 1945; Fortes 1950; McLeod 1981; Abu 1983).

Abron. A aldeia abron compõe-se de dois tipos de casa - as casas dos homens e as casas das mulheres - dispostas em torno de uma praça central onde se situam o palácio do rei e a casa da rainha-mãe (na verdade, freqüentemente, a irmã mais velha do rei). As casas dos homens, domicílios coletivos onde estes comem juntos, consistem em grandes edifícios retangulares com pátios internos (e, no caso do palácio real, um grande salão de reunião), claramente separados das casas das mulheres e das cozinhas abertas que os abastecem de alimentos. Os dois tipos de casa são igualmente transmitidos em linha uterina, as alianças entre elas sendo estabilizadas pela regra de casamento com a prima cruzada matrilateral. Todavia, as casas dos homens são habitadas por grupos agnáticos, que se mudam, cada vez que morre o mais velho, com a chegada de seu herdeiro uterino, de modo que a mesma regra 
de casamento que estabiliza os laços entre as casas uterinas implica uma circulação permanente de seus moradores agnáticos. A mesma lógica aplica-se ao palácio real — com a diferença, apenas, de que os descendentes paternos do rei recorrem ao casamento com a prima cruzada patrilateral para recuperar mais rapidamente o trono e reduzir o número de patrilinhagens reais a duas, que partilham o trono alternadamente, uma fornecendo o rei e a outra o príncipe consorte (Alland 1984; Terray 1993).

Baulé. A aldeia baulé consiste em vários pátios (aulo), compostos de cabanas retangulares construídas sobre uma área mais ou menos compacta e contínua, separados um do outro por estreitas passagens, algumas vezes agrupados em quarteirões, mas sem nenhum centro comum. Em comparação com os outros grupos akan (Axanti ou Abron), o princípio matrilinear, já enfraquecido entre os últimos, reduz-se aqui a uma fraca inflexão: os Baulé não possuem nem matrilinhagens, nem rainha-mãe. Se o homem escolhe permanecer, após o casamento, em seu sítio natal, sua esposa pode ali reunir-se a ele depois que ele lhe construir uma casa. Freqüentemente, entretanto, ela permanece com seus próprios parentes até o nascimento do terceiro filho, ainda que cozinhando para seu marido, como fazem os Abron. E, mesmo depois, seu retorno ao pátio natal permanece uma opção sempre aberta. O homem não pode garantir a residência virilocal da esposa (e, sobretudo, a residência patrilocal dos filhos) a não ser por um fluxo incessante de dons, e não pode torná-la definitiva senão por uma prestação considerável, que caracteriza uma forma de casamento particular (ato-vle), similar à instituição do dote nas sociedades patrilocais, mas limitada aos chefes. O pátio - essencialmente ambilocal, pois — constitui assim a unidade exógama (enquanto que os quarteirões tornam-se endógamos e não mantêm entre si relações recíprocas). Em conformidade com sua composição cognática, os interditos matrimoniais se estendem a todos os descendentes de um ascendente vivo (ainda que o incesto propriamente dito diga respeito apenas aos uterinos). Ao mesmo tempo, o interdito de redobramento se estende aos casamentos de todos os germanos (incluindo os de sexo oposto), e mesmo aos aliados de aliados. A abolição da residência unilocal implica pois, simultaneamente, a emergência de uma estrutura de parentesco "complexa" e a descentralização da morfologia espacial (Etienne 1972; 1975; Chauveau 1977; Weiskel 1978).

Guro orientais. Na parte florestal do país guro (no leste e no sul), as aldeias compõe-se de grandes casas complexas construídas dos dois lados de um caminho central (doogi) que funciona como praça pública e é utilizado por ocasião das cerimônias masculinas proibidas às mulheres (razão pela qual as cabanas lhe dão as costas). As casas (guniwuo, "fogo principal"), 
que ao longo do tempo desenvolvem-se em quarteirões inteiros e se segmentam em novas casas, são compostas de dois tipos de construção: as grandes cabanas redondas (guluko), divididas em compartimentos para o marido e suas esposas, dispõem-se próximo ao centro, enquanto que os galpões $(b a)$, que servem como espaços de socialização seja femininos (cozinhas coletivas) seja masculinos (centro de recepção e de debates), formam uma espécie de cinturão na periferia. As casas constituem comunidades comensais (cada uma com um galpão para refeições coletivas) e unidades de troca em termos matrimoniais - o dote para um membro feminino que parte é utilizado para a aquisição de uma esposa para um membro masculino. Como a apresentação do dote é uma condição para a residência patri-virilocal, a renúncia ao dote constitui, para a casa dos doadores, um método de recrutamento de novos membros: o sobrinho uterino é então integrado à casa materna, enquanto que seus agantos podem formar uma nova casa no quarteirão dos afins. Assim, o quarteirão pode evoluir, por meio de anexações sucessivas dos tomadores de mulheres a uma casa central. A proibição de alianças matrimoniais com as casas de todos os parentes conhecidos acarreta uma extensão progressiva da área exogâmica em torno desse centro - no limite, a própria tribo (be), grupamento territorial de várias aldeias, tende a se definir como um clã exógamo. De outro lado, e segundo uma dialética essencial para o funcionamento dos sistemas "semi-complexos", o processo de segmentação reestabelece continuamente a possibilidade de novas alianças entre casas derivadas de casas aliadas, ou mesmo de uma única casa ancestral (Meillassoux 1964; Deluz-Chiwa 1965).

Dida e Bete. As aldeias dida e bete são organizadas em várias casas (sere, em dida, sue, em bete), dispostas dos dois lados de uma rua central (tsrekpa), no meio ou extremidade da qual se encontra a árvore do parlamento. A casa, ou melhor, o pátio familiar, compreendendo a cabana principal do marido e as cozinhas de suas esposas, representa ao mesmo tempo o germe e o modelo estrutural para todas as unidades mais englobantes que se desenvolvem, a partir dela, pelo processo de segmentação da patrilinhagem: em particular, cada grupo derivado de uma mesma casa (quer dizer, do mesmo pai) se divide em vários grupos derivados da mesma cabana (quer dizer, da mesma mãe). O segmento que constitui a unidade matrimonial é definido pelo mecanismo do dote: o mais velho do segmento recebe o dote pelos membros femininos, os utiliza para o casamento dos membros masculinos, e garante assim a incorporação de seus filhos enquanto membros futuros, o que estabelece, ao mesmo tempo, os laços de aliança e de filiação (não apenas entre pai e filho/a mas, igualmente, entre mais velho e mais novo: pertence-se sempre ao segmento daquele que forneceu o dote). A rede de parentesco é, pois, costurada pela circulação 
do dote. Como a dinâmica do sistema repousa sobre o princípio de não-redobramento das alianças entre as unidades, a extensão da área de exogamia depende da velocidade do processo de segmentação: por exemplo, se todos os grupos proibem a poliginia sororal e o casamento com a prima cruzada matrilateral, os Bete de Daloa, entretanto, autorizam o casamento com a prima cruzada matrilateral do meio-irmão agnático, e os Dida orientais permitem o casamento com a prima cruzada patrilateral. Como as relações entre aliados são geralmente belicosas, o casamento serve, primeiro, para manter um laço de comunicação pacífico - não tanto por intermédio das mulheres, que o concebem antes como um exílio em país hostil, quanto de seus filhos, que mantêm uma posição privilegiada em seu "país materno" e, sobretudo, na casa de seu tio materno. Esta posição se manifesta não apenas nos privilégios do sobrinho uterino, bem conhecidos em toda África ocidental patrilocal (intrusão transitória e amigável na casa avuncular, que é na verdade uma transformação da intrusão definitiva e hostil característica das sociedades do tipo Abron). Ela se manifesta igualmente no costume de atribuir a cada esposa um membro residente de seu matriclã (yuru em Dida, lele em Bete), isto é, um tio materno classificatório que desempenha o papel de protetor e que constrói, com outros membros do matriclã, sua cabana (ou uma parte simbólica). A cabana materna - germe de todos os segmentos futuros da patrilinhagem — se apresenta pois como uma construção coletiva do matriclã que ela representa, como notou Dozon, no seio do sítio patrilocal (o agrupamento espacial da aldeia em matriclãs é reservado para algumas ocasiões cerimoniais). Mas, sobretudo, a importância do laço uterino se exprime na preferência explícita dos dois sexos por um casamento "em país materno": princípio oposto àquele do não-redobramento das alianças, que pode todavia ser compensado por instituições que garantam a reunião (mesmo que temporária) dos parentes uterinos dispersos. Essa conexão entre a extensão dos interditos matrimoniais e a restauração periódica da matrilocalidade no seio de sociedades patrilocais - conexão já atestada, sob um outro ângulo, por Luc de Heusch (1978) — evoca claramente o papel da dupla morfologia na América do Norte (Paulme 1962; Terray 1969; Marie 1972; Dozon 1985).

\section{Resumo}

Além dos traços já observados nos exemplos americanos, devemos reter o seguinte:

- uma organização "fractal" do espaço, resultante de uma dinâmica segmentar que transforma as cabanas maternas (grupos de germanos uterinos) pri- 
meiro em casas (segmentos de linhagem), depois em quarteirões ou aldeias (linhagens autônomas);

- um princípio geral de multiplicação das alianças por meio do não-redobramento dos casamentos do grupo (tal como definido pelo processo segmentar), o que implica, em caso de virilocalidade, uma organização concêntrica ao nível local (cada cabana componente representando uma casa aliada diferente);

- uma forte valorização do laço de parentesco complementar à regra de residência, valorização que se manifesta, no caso uxorilocal, pela constituição de grupos agnáticos temporários nas casas dos homens, e, no caso virilocal, pela facilidade da passagem física e simbólica entre a cabana materna e a casa avuncular, um traço que parece tanto mais marcado quanto as áreas matrimoniais são descentralizadas.

\section{Esboço de um modelo geral}

É evidente que um simples modelo não pode dar conta de todas as variações morfológicas cujos traços salientes acabamos de indicar, e cuja compreensão exigiria uma análise transformacional que não podemos empreender aqui. Nosso interesse presente limita-se a um único invariante, a saber, a interdependência que parece existir entre:

a) a maneira como o regime matrimonial tende a multiplicar ou limitar o número de alianças matrimoniais estabelecidas por um grupo residencial, e b) a maneira como o regime residencial (aí incluída a arquitetura da moradia) permite a homens e mulheres a co-residência permanente ou temporária com seus consangüíneos de mesmo sexo (mais precisamente, falarei em regime harmônico quando for permitido a ambos os sexos indiferentemente a coresidência com consangüíneos seja agnáticos, seja uterinos, e em regime desarmônico quando este implicar a co-residência com os agnatos para um dos sexos, a co-residência com os uterinos para o outro).

Abordarei essa questão recordando o princípio fundamental de um espaço de parentesco fundado sobre a organização residencial: viver com consangüíneos e casar-se com vizinhos. Ora, como já mencionado mais acima, o fato de que casamento acarreta igualmente uma forma de co-residência implica um conflito latente entre a co-residência de consangüíneos e a co-residência de esposos. Com efeito, um sistema que põe grupos em comunicação por meio do deslocamento de seus membros não pode escapar a essa dificuldade, a não ser supondo de saída duas classes de indivíduos, 
uns (que permanecem fixos) comunicando-se por intermédio dos outros (que circulam). Mas nada indica que os indivíduos "circulantes" renunciem por isso a formar grupos de consangüíneos. Pelo contrário, muitas estruturas matrimoniais e residenciais parecem justamente ter como função garantir a todos os indivíduos - homens e mulheres igualmente - a possibilidade de residir com seus consangüíneos de mesmo sexo, mesmo se eles deixaram seus consangüíneos de sexo oposto para unirem-se a seus esposos. Ora, para resolver o conflito latente entre os dois imperativos residenciais, três soluções diferentes são logicamente possíveis: 1) um regime que permita a residência simultânea com afins e consangüíneos (que chamarei de modelo conjuntivo, segundo a natureza do laço lógico que ele estabelece entre os dois princípios de residência); 2) um regime que acarrete uma residência alternada, ora com afins, ora com consangüíneos (que chamarei de modelo disjuntivo); 3) finalmente, um regime que faz com que se resida com consangüíneos enquanto afins, a co-residência dos afins implicando ipso facto aquela dos consangüíneos (que chamarei de modelo implicativo).

\section{O modelo conjuntivo e as estruturas "elementares"}

Para tornar possível a residência simultânea com afins e consangüíneos, basta adotar um regime matrimonial que implique o redobramento sistemático de cada casamento pelos consangüíneos do casal. Desta maneira, os indivíduos que deixaram seus grupos de origem para casar-se encontrarão sempre consangüíneos no seio dos grupos de destino. Se esses consangüíneos são de mesmo tipo (agnático ou uterino) para o marido e para a esposa (caso harmônico), esta solução resulta na formação de "colônias" por aqueles provenientes da mesma residência de origem. Neste caso, cada grupo de consangüíneos é dividido em um subgrupo que retém a casa natal e um outro que a representa no seio da casa aliada. Inversamente, cada casa é dividida em uma parte que abriga os "autóctones" e uma outra que agrupa os "colonos". O regime matrimonial clássico para alcançar uma tal situação é o casamento com a prima cruzada matrilateral. Não é pois surpreendente encontrá-lo associado - como nos exemplos indonésios - a uma divisão diametral das casas e a mitos de origem que evocam uma união primordial entre autóctones e imigrantes.

No caso disarmônico, por outro lado, o deslocamento implicado pelo casamento não apenas não consiste em uma ameaça para a coesão dos consangüíneos, mas serve-lhes justamente de meio para se constituirem enquanto grupo: eis porque o casamento paradigmático deste tipo - aquele com a prima cruzada patrilateral — é a estratégia ideal dos grupos de filia- 
ção que não são grupos residenciais para escapar à dispersão e reencontrar uma estabilidade relativa em torno de duas residências alternadas. Conseqüentemente, encontramo-la freqüentemente associada a traços bilineares e a uma certa ambigüidade na caracterização agnática ou uterina do grupo residencial, ambigüidade que se resolve em certos casos (que não discutimos aqui, como por exemplo a Costa Noroeste da América do Norte ou a Amazônia ocidental) por uma alternância de funções do mesmo edifício físico, ora casa profana abrigando os consangüíneos, ora casa cerimonial reunindo os afins. Uma tal alternância é, na verdade, uma transformação, no plano temporal, do modelo disjuntivo discutido abaixo, o que pode explicar a freqüente inflexão patrilateral nas sociedades que resolvem os conflitos de um regime desarmônico pela instituição de uma dupla residência.

\section{O modelo disjuntivo e as estruturas "semi-complexas"}

A residência alternada com afins e consangüíneos implica que indivíduos casados permaneçam ligados a uma residência comum fora de seus grupos de destino e considerem o domicílio junto aos afins como uma situação transitória (cujo caso extremo é a visita noturna). No caso harmônico, essas residências externas podem coincidir com as residências natais, o que resulta em um sistema natolocal, ilustrado pelo sistema "puro" dos Axanti (ou ainda dos Minangkabau na Indonésia ocidental), mas também - em um grau menor - em um bom número de sistemas classificados como "virilocais", que envolvem, na verdade, longas estadias intermitentes das mulheres casadas com seus parentes paternos. O fato de que esses mesmos sistemas exibam freqüentemente uma tendência ao casamento com a prima cruzada matrilateral, e que a divisão diametral em lados masculino e feminino possa igualmente caracterizar casas que abrigam apenas consangüíneos, indica a proximidade transformacional entre esses sistemas e os de "troca generalizada" discutidos acima. Em compensação, a realização do modelo disjuntivo em um quadro desarmônico implica necessariamente a separação de residências sexuadas - seja no espaço, como ilustrado pelas casa-dos-homens brasileiras, seja no tempo, como exemplificado pela dupla morfologia das planícies norte-americanas.

A diferença fundamental entre esse modelo e o modelo conjuntivo reside no fato de que ele não exige o redobramento dos casamentos além do mínimo necessário para manter a aliança (no limite, um só representante em cada grupo, em um momento dado, é suficiente). Ele permite pois uma multi-

plicação de alianças entre grupos unilineares, e aparece assim como quadro ideal para os sistemas ditos "semi-complexos". Ao contrário das estruturas 
"elementares" engendradas pelo modelo conjuntivo, o qual tende a minimizar os aliados de cada grupo e a produzir morfologias lineares, o modelo disjuntivo engendra redes matrimoniais bem mais densas, o que - na hipótese de que cada sociedade buscaria minimizar a distância média entre os cônjuges - favorece a morfologia concêntrica que observamos em muitas sociedades desse tipo, seja de forma sincrônica, como na oposição "sul-americana" entre centro masculino e periferia feminina, seja de forma diacrônica, como no ritmo "norte-americano" entre concentração agnática e dispersão uterina. É preciso, entretanto, acrescentar que esse dualismo concêntrico não é a única morfologia compatível com um modelo disjuntivo. O reagrupamento das parentas uterinas nas aldeias virilocais da África ocidental sublinhado por Héritier (1981 e comunicação pessoal) — não se exprime na mesma morfologia que o agrupamento dos agnatas masculinos em uma aldeia uxorilocal no Brasil. Parece, além disso, que, diferentemente do modelo conjuntivo, as estruturas engendradas pelo modelo disjuntivo não são neutras com relação ao sexo que determina a residência. Mas a formação de espaços femininos em sociedades virilocais é ainda muito pouco estudada para que possamos tirar conclusões pertinentes.

\section{O modelo implicativo e as estruturas "complexas"}

Consideremos enfim brevemente - pois não tratamos de exemplos desse tipo senão marginalmente - a terceira solução para o conflito entre a coresidência de consangüíneos e a co-residência de afins, solução que consiste em separar inteiramente a escolha residencial do critério sexual, e garantir assim a formação automática de grupos de consangüíneos de mesmo sexo independentemente de qualquer arranjo matrimonial ou residencial: mesmo casando-se no estrangeiro, poder-se-á sempre formar um grupo de consangüíneos com certos filhos de mesmo sexo, cuja residência pós-marital não será mais predeterminada. Liberada de todas as restrições que limitariam a construção de uma rede matrimonial ao mesmo tempo densa e extensa, uma estrutura composta de grupos ambilocais apareceria, com efeito, como o modelo ideal de um espaço de parentesco. Entretanto, uma tal estrutura arriscaria-se, bem mais que as estruturas unilineares, a perder a propriedade fundamental de um espaço, a saber, a homogeneidade. Como o destino residencial não depende mais do sexo, o interdito do incesto, por si só, não é suficiente para impedir a formação de tomadores ou doadores absolutos: um grupo poderoso pode bem atrair todos os cônjuges de seus filhos e filhas, enquanto um grupo fraco pode perder todos os seus membros devido à força de atração de seus vizinhos. Para que uma tal 
estrutura permaneça homogênea, o simples mecanismo da exogamia deve ser substituído por um jogo complexo de forças que se contrabalançam mutuamente. É este tipo de estrutura complexa - exemplificada pela Indonésia central ou pela Costa Noroeste central norte-americana - que Lévi-Strauss (1979) batizou de "sociedades de Casas" (em contraste com sociedades com grupos de filiação). Até o presente, não existem estudos que tenham empreendido uma análise geral do funcionamento dessas sociedades. Uma tal análise seria tanto mais importante quanto o jogo estratégico das "casas" indiferenciadas representa, em um certo sentido, o modelo mais geral do qual resultam os dois outros modelos tratados, quando se "fixa" uma das variáveis do sistema, a saber, a escolha residencial. Essas reflexões ultrapassam todavia os limites do presente estudo.

\section{Conclusão}

Avancei aqui um duplo argumento: o de que a função dos sistemas de parentesco consiste em engendrar estruturas de espaço (das quais as estruturas de troca representam um caso especial), e o de que a escolha particular do código residencial e genealógico que eles empregam nesse sentido determina, em uma certa medida, a estrutura resultante.

Para justificar a hipótese de base, sublinhei o papel fundamental que uma rede homogênea de relações sociais joga na objetivação da experiência intersubjetiva - dito de outra maneira, na constituição de uma sociedade enquanto tal, se o traço característico de uma sociedade é a comparabilidade e comunicabilidade das relações entre seus membros. O sistema de parentesco converte as inumeráveis interações entre os humanos em signos discretos de uma linguagem universal, signos que têm um sentido para cada um, ainda que ninguém os articule da mesma maneira, e cujo sentido consiste, justamente, em conferir sentido a todas as articulações do outro. Esta é a significação da isomorfia entre posições e permutações que caracteriza toda estrutura espacial. Desse ponto de vista, o parentesco não é uma instituição social entre outras, mas uma condição de possibilidade para toda experiência social propriamente dita - experiência que não apenas implica um outro mas que é também comunicável a um terceiro. Essa comunicabilidade universal é o traço distintivo de uma rede homogênea - nenhum superior que não tenha um superior, nenhum sucessor que não tenha sucessor, nenhum tomador que não tenha tomador. O princípio da reciprocidade, com efeito, não constitui senão um aspecto particular do princípio de homogeneidade, e a igualdade característica de todo sistema de troca não é senão a conseqüência de uma 
igualdade mais fundamental que é constitutiva da possibilidade de um mundo social comum. Compreende-se assim porque o campo do parentesco define, para muitas sociedades, os limites da humanidade.

Entretanto, se a função do parentesco enquanto espaço social exibe assim um caráter, por assim dizer, a priori, isso não é verdade para o simbolismo escolhido para construir este espaço - no caso, os códigos genealógico e residencial. Nada indica que o parentesco seja a única instituição capaz de cumprir essa função. Em compensação, a natureza particular de seu código impõe um constrangimento suplementar às estruturas espaciais que ela pode produzir. Como a rede de parentesco é costurada pelo deslocamento de indivíduos entre grupos, todo princípio de recrutamento que não preveja a integração dos indivíduos "circulantes" em seus grupos de destino acarreta um conflito potencial entre o papel de intermediário e o pertencimento a um grupo localizado. Discutimos diversos modelos que permitem solucionar este conflito por meio de um regime matrimonial e/ou morfologia residencial particular. Ora, se a estrutura da rede social depende assim da técnica por meio da qual é costurada, a emergência de diferentes estruturas de parentesco deveria explicar-se, no fim das contas, pelos fatores que determinam a escolha de uma técnica em lugar da outra - a divisão sexual do trabalho, a topografia do hábitat, o modo de produção etc. Essas questões não são novas, mas a concepção aqui desenvolvida talvez permita recolocá-las de uma nova perspectiva.

O problema fundamental da teoria das estruturas de parentesco consiste em distinguir os traços que remetem à sua função social comum daqueles traços que resultam de circunstâncias históricas particulares. Identificando os traços gerais àqueles próprios a uma estrutura espacial e ligando os traços particulares à organização residencial, apresentei os princípios de uma teoria "espacial" do parentesco. A fecundidade de uma tal teoria dependerá do sucesso da análise transformacional de um corpus extenso e contínuo de estruturas de parentesco, único método capaz de identificar seus invariantes e de compreender a lógica de suas variações.

Recebido em 15 de outubro de 2004

Aprovado em 13 de dezembro de 2004

Tradução de Marcela Coelho de Souza

Karl Hamberger é pesquisador do Laboratoire d'Anthropologie Sociale (LAS) da École des Hautes Études en Sciences Sociales, Paris. E-mail: < klaus_ hamberger@yahoo.fr> 


\section{Notas}

${ }^{1}$ Se todo espaço se caracteriza pelo fato de que dois pontos definem uma permutação única, isso não implica, em geral, que dois pontos definam também uma reta única. Para que essa última condição seja satisfeita, é preciso que o grupo de permutações não apenas seja regular mas também comutativo (o que é o caso de todo espaço afim, como o espaço euclidiano).

2 Entenda-se, é o sistema inteiro das atitudes mútuas - comportamentos ou expectativas - que está em jogo aqui, mais do que atitudes individuais. Pode-se ser um mau irmão e um marido pior ainda, contanto que não se trate a irmã como uma esposa, o que aboliria o próprio critério do bom e do mau, e reduziria os comportamentos, destacados de sua significação social, a puras expressões subjetivas e, no limite, incomunicáveis.

${ }^{3}$ Não se trata aqui de propor uma nova classificação das estruturas de parentesco, mas apenas de uma nova interpretação da classificação tradicional. 


\section{Referências bibliográficas}

ABU, Katherine. 1983. "Separateness of spouses: conjugal resources in an Ashanti town". In: C. Oppong (org.), Female and male in West Africa. London: Allen \& Unwin. pp.156-168.

ADAMS, Marie Jeanne. 1980. "Structural aspects of east sumbanese art". In: J. Fox (org.), The flow of life: essays on Eastern Indonesia. Cambridge, Mass.: Harvard UP. pp. 208-220.

ALLAND, Alexander Jr. 1984. La danse de l'arraignée. Un ethnologue américain chez les Abron (Côted'Ivoire). Traduzido do inglês por Didier Pemerle. Paris: Plon.

BAILEY, Garrick A. 2001. "Osage". Handbook of North American Indians, 13(1):476-496.

BOWERS, Alfred W. 1991 [1950]. Mandan social and ceremonial organization. Moscow: University of Idaho Press.

. 1965. "Hidatsa social and ceremonial organization". Bureau of American Ethnology, Bulletin 194. Washington: Government Printing Office.

BUSHNELL, David I. 1922. "Villages of the Algonquian, Siouan, and Caddoan tribes west of the Mississippi". Bureau of American Ethnology, Bulletin 77. Washington: Government Printing Office.

CHAUVEAU, Jean-Pierre. 1977. "Société baoule précoloniale et modèle segmentaire. Le cas de la région de
Kokumbo". Cahiers d'Études Africaines, 68 (XVII-4):415-434.

CLAMAGIRAND, Brigitte. 1980. "The social organization of the Ema of Timor". In: James J. Fox (org.), The flow of life: essays on Eastern Indonesia. Cambridge, Mass.: Harvard UP. pp. 134-151.

COLBACCHINI, Antonio. 1996 [1942]. The eastern Bororo Orarimogodogue of the eastern plateau of Mato Grosso. New Haven, Conn.: Human Relation Area Files. Traduzido por Ivana Lillios.

COURRÈGE， P. 1965. "Un modèle mathématique des structures élémentaires de parenté". L'Homme 5 (3-4):248-90.

CROCKER, J. Christopher. 1979. "Selves and alters among the Eastern Bororo". In: D. Maybury-Lewis (org.), Dialectal societies. The Gê and Bororo of Central Brasil. Cambridge, Mass. and London: Harvard University Press. pp. 249-300.

CUNNINGHAM, Clark. 1964. "Order in the Atoni house". Bijdragen tot de Taal-, Land- en Volkenkunde, 120:34-68. . 1967."An Atoni village of west Timor". In: Koentjaraningrat (org.), Villages in Indonesia. Ithaca: Cornell University Press. pp. 63-89.

DAMATTA, Roberto. 1979. "The Apinayé relationship system: terminology and ideology". In: D. Maybury- 
Lewis (org.), Dialectal societies. The Gê and Bororo of Central Brasil. Cambridge, Mass. and London: Harvard University Press. pp. 83-127. 1982. A divided world. Apinayé social structure.Cambridge, Mass. and London: Harvard University Press. Traduzido por Alan Campbell. DANQUAH, Joseph Boakye. 1945. The gold coast Akan. London: United Society for Christian Literature.

DE HEUSCH, Luc. 1978. "La dette sacrée de l'oncle maternel. Contribution à l'étude des structures complexes de la parenté". In: Systèmes de signes. Textes réunis en hommage à Germaine Dieterlen. Paris: Hermann. pp. 271-298.

DELUZ-CHIWA, Ariane. 1965. "Villages et lignages chez les Guro de Côte d'Ivoire". Cahiers d'Études Africaines, V (19):388-482.

DÉSVEAUX, Emmanuel. 2001. Quadratura americana. Essais d'anthropologie levi-straussienne. Genève: Georg.

DIETSCHY, Hans. 1976. "Espace social et 'affiliation par sexe' au Brésil Central (Karajá, Tapirapé, Apinayé, Mundurucú)". Actes du XLIIe Congrès International des Américanistes, Congrès du Centenaire, vol. II:297-308.

DORSEY, James Owen. 1884. "Omaha Sociology". Third annual report of the Bureau of Ethnology to the secretary of the Smithsonian Institution, 1881-1882. Washington: Government Printing Office. . 1897. "Siouan Sociology". Fif- teenth annual report of the Bureau of Ethnology to the secretary of the Smithsonian Institution, 1893-1894. Washington: Government Printing Office.

DOZON, Jean-Pierre. 1985. La société bété. Histoires d'une "ethnie" de Côte-d'Ivoire. Paris: Kathala-Orstom.

DREYFUS, S. 1963. Les Kayapo du nord. Contributions à l'étude des indiens Gé. Paris: Mouton.

ETIENNE, Pierre. 1972. Les interdictions de mariage chez les Baoule (texto provisório). Abidjan: Orstom. . 1975. Les interdictions de mariage chez les Baoule. L'-Homme, 15(34): 5-29.

FABIAN, Stephen Michael. 1992. Space-time of the Bororo of Brazil. Gainesville, Fla.: University Press of Florida.

FLETCHER, Alice C. 1904. "The Hako: a pawnee ceremony". Twentysecond annual report of the Bureau of American Ethnology to the secretary of the Smithsonian Institution, 1900-1901. Washington: Government Printing Office.

FLETCHER, Alice C. e La Flesche, Francis. 1911. "The Omaha tribe". Twenty-seventh annual report of the $\mathrm{Bu}$ reau of American Ethnology to the secretary of the Smithsonian Institution, 1905. Washington: Government Printing Office.

FORDE, Cyril Daryll. 1950. The blackfoot: buffalo hunters of the north american plains. London/New York: Methuen, Dutton. 
FORTES, Meyer. 1950. "Kinship and marriage among the Ashanti". In: A. R. Radcliffe-Brown e D. Forde (orgs.), African systems of kinship and marriage. London: Oxford University Press for the International African Institute . pp. 252-284.

FORTH, Gregory L. 1981. Rindi. An ethnographic study of a traditional domain in eastern Sumba. The Hague: Nijhoff.

FRANCILLON, Gérard. 1968. "Un état sans pouvoir, structure sociale et familiale des Tetun du sud (Timor central)". In: VIIIth Congress of Anthropolocial and Ethnological Sciences. Tokyo, Science Council of Japan. pp. 102-3.

1989. "Un profitable échange de frères chez les Tetun du sud, Timor central". L'Homme 109, XXIX (1):26-43.

GEERTZ, Clifford. 1964. "Tihingan: a balinese village". Bijdragen tot de Taal, Land en Volkenkunde, 120:1-33.

GEERTZ, Hildred e Geertz, Clifford. 1975. Kinship in Bali. Chicago: University of Chicago Press.

HÉRITIER, Françoise. 1981. L'exercice de la parenté. Paris: Gallimard.

BAILEY, Garrick A. e La Flesche, Francis. 1995. The Osage and the invisible world from the works of Francis la Flesche. Norman: University of Oklahoma Press.

LÉVI-STRAUSS, Claude. 1936. "Contribution à l'étude de l'organisation sociale des indiens Bororo". Journal de la Société des Américanistes, XVIII (2)*.
LÉVI-STRAUSS, Claude. 1958 [1952]. "Les structures sociales dans le Brésil central et oriental". In: Anthropologie Structurale. Paris : Plon. pp. 133-145.

. 1958 [1956a]. " Les organisations dualistes existent-ils?. In: Anthropologie Structurale. Paris: Plon. pp. 147-180.

_. 1958 [1956 b]. " Structure et dialectique". In: Anthropologie Structurale. Paris : Plon. pp. 257-266. 1979. "L'organisation sociale des Kwakiutl". In: La voie des masques. Paris: Plon. Edição revista e aumentada.

LIBERTY, Margot P; Wood, Raymond e Irwin, Lee. 2001. "Omaha”. Handbook of North American Indians, 13(1):399-415. Washington, D.C.: Smithsonian Institution Press.

LIPKIND, W. 1963."The Caraja". Handbook of South American Indians, 3:179191. New York: Cooper Square Publ.

LORRAIN, F. 1975. Réseaux sociaux et classifications sociales. Essai sur l'algèbre et la géométrie des structures sociales. Paris: Hermann.

LOWIE, Robert H. 1935. The Crow indians. New York : Farrar \& Rinehart. 1963. "The northwestern and central Ge". Handbook of South American Indians, 1:477-517. New York: Cooper Square Publ.

MARIE, Alain. 1972. “Parenté, échange matrimonial et réciprocité. Essai d'interprétation à partir de la société dan et de quelques autres sociétés de Côte d'Ivoire". L'Homme, XII (3):5-46. 
MAYBURY-LEWIS, David. 1967. Akwe-Shavante society. Oxford: Clarendon Press. . 1979. "Cultural categories of the central Gê". In:__. (org.), Dialectal societies. The Gê and Bororo of Central Brasil. Cambridge, Mass. and London: Harvard University Press. pp. 218-246.

MCKINNON, Susan. 1991. From a shattered sun. Hierarchy, gender, and alliance in the Tanimbar Islands. Madison: University of Wisconsin Press.

. 1995. "Houses and hierarchy: the view from a South Moluccan society". In: J. Carsten e S. Hugh-Jones (org.), About the house. LéviStrauss and beyond. Cambridge: Cambridge UP. pp. 170-188.

2000. "The tanimbarese tavu: the ideology of growth and the material configurations of houses and hierarchy in an indonesian society". In: R. Joyce e S. Gillespie (orgs.), Beyond kinship. Social and material reproduction in house societies. Philadelphia: University of Pennsylvania Press. pp. 161-176.

MCLEOD, Malcolm D. 1981. The Asante. London: British Museum $\mathrm{Pu}-$ blications.

MEILLASSOUX, Claude. 1964. Anthropologie économique des Gouro de Côte d'Ivoire. De l'économie de subsistance à l'agriculture commerciale. Paris: Mouton.

MOORE, John H. 1987. The cheyenne nation. A social and demographic history. Lincoln: University of Nebraska Press.
MOORE, John H.; Liberty, Margot P. e Straus, A. Terry. 2001. "Cheyenne". Handbook of North American Indians, 13(2):863-885. Washington: Smithsonian Institution Press.

MURIE, James R. 1989. Ceremonies of the Pawnee. Lincoln: University of Nebraska Press for the American Indian Studies Research Institute, Indiana University.

MURPHY, Robert Francis. 1954. The Rubber Trade and the Munduruc Village. Ph.D. Thesis, Columbia University. . 1960. Headhunter's heritage: social and economic change among the Mundurucú indians. Berkeley: University of California Press.

NADELSON, Leslie. 1981. "Pigs, women, and the men's house in Amazonia: an analysis of six Mundurucu myths". In: S. Ortner e H. Whitehead (orgs.), Sexual meanings. The cultural construction of gender and sexuality. Cambridge: Cambridge UP. pp. 240-272.

NEEDHAM, Rodney. 1980. "Principles and variations in the structure of sumbanese society". In: J. Fox (org.), The flow of life: essays on Eastern Indonesia. Cambridge, Mass.: Harvard UP. pp. 21-44.

PARKS, Douglas R. 2001. "Pawnee". Handbook of North American Indians, 13(1):515-547. Washington, D.C.: Smithsonian Institution Press.

PAULME, Denise. 1962. Une société de Côte d'Ivoire hier et aujourd'hui: les Bété. Paris: Mouton. 
PÉTESCH, Nathalie. 1992. La pirogue de sable. Modes de représentation et d'organisation dans une société du fleuve: les Karaja de l'Araguaia (Brésil central). Thèse du 3e cycle, Université Paris X.

RATTRAY, Robert Sutherland. 1929. Ashanti law and constitution. Oxford, England: Clarendon Press.

SCHULTE-NORDHOLT, H. G. 1971. The political system of the Atoni of Timor. The Hague: Nijhoff. . 1980. "The symbolic classification of the Atoni of Timor". In: J. Fox (org.), The flow of life: essays on Eastern Indonesia. Cambridge, Mass.: Harvard UP. pp. 231-247.

STEWART, Frank Henderson. 2001. "Hidatsa". Handbook of North American Indians, 13(1):329-348. Washington, D.C.: Smithsonian Institution Press

TERRAY, Emmanuel. 1969. L'organisation sociale des Dida de Côte d'Ivoire. Essai sur un village dida de la région de Lakota. Annales de l'Université d'Abidjan, Série F, Tome 1, Fascicule 2.

. 1993. "Le système politique abron et l'introduction du mariage patrilatéral". In: F. Héritier-Augé e E. Coupet-Rougier (orgs). Les complexités de l'alliance, vol. III: Economie, politique et fondements symboliques (Afrique). Paris: Ed. des Archives Contemporaines. pp. 1-12.
TJON SIE FAT, F. 1990. Representing kinship: simple models of elementary structures. Ph.D. Thesis, Rijksuniversiteit Leiden.

TURNER, Terence S. 1979. "Kinship, household, and communtiy structure among the Kayapó". In: D. Maybury-Lewis (org.), Dialectal societies. The Gê and Bororo of Central Brasil. Cambridge, Mass. and London: Harvard University Press. pp. 179-214.

VAN WOUDEN, F. A. E. 1968 [1935]. Types of social structure in Eastern Indonesia (Sociale structuurtypen in de Groote Oost), traduzido por Rodney Needham. The Hague: Nijhoff.

VOGET, Fred W. 2001. "Crow". Handbook of North American Indians, 13(2):695-717. Washington, D.C.: Smithsonian Institution Press.

WATERSON, Roxana. 1991. The living hose. An anthropology of architecture in South-East Asia. Singapore: Oxford University Press.

WEISKEL, Thimoty C. 1978. "The precolonial baule: a reconstruction". Cahiers d'Études Africaines, 72 (XVIII-4):503-560.

WOOD, W. Raymond e Irwin, Lee. 2001. "Mandan". Handbook of North American Indians, 13(1)349-364. Washington, D.C.: Smithsonian Institution Press. 


\section{Resumo}

Partindo de algumas similaridades formais cruciais entre o parentesco e as estruturas espaciais (ambas concebidas como estruturas de percepção das relações mútuas), o artigo propõe tratar a organização matrimonial e residencial como formando um sistema único, que não pode ser entendido a partir de suas partes isoladas. A partir dessa perspectiva, as múltiplas combinações empíricas dos padrões de casamento e residência apresentam-se como soluções diferentes para a mesma questão: o problema de relacionar grupos de parentesco que enviam continuamente membros para outros grupos, sem que esses membros 'móveis' sejam desvinculados de seu grupo de parentesco original. De acordo com a forma como o parentesco e sua transmissão são concebidos, três tipos básicos de soluções se apresentam, cada qual originando um modelo diferente de casamento e organização de residência. Esses modelos são aplicados a evidências etnográficas de quatro diferentes partes do mundo (Indonésia Oriental, Brasil Central, Vale do Missouri e Costa da Guiné).

Palavras-chave Parentesco, Espaço, Residência, Casamento, Antropologia Estrutural

\section{Abstract}

Starting from some crucial formal similarities between kinship and space structures (both being conceived of as structures of mutual perception relations), the article proposes to treat matrimonial and residential organization as forming one single system, no part of which can be properly understood if taken in isolation. From such a perspective, the manifold empirical combinations of marriage and residence patterns present themselves as different solutions to the same problem: the problem of linking localized kin groups by continuously sending members from one group into another, without thereby detaching the "mobile" members from their kin. According as how kinship and its transmission are conceived, three basic types of solutions present themselves, each giving rise to a different model of marriage and residence organization. These models are applied to ethnographic evidence from four different parts of the world (Eastern Indonesia, Central Brazil, Missouri Valley and Guinea Coast).

Key words Kinship, Space, Residence, Marriage, Structural Anthropology 